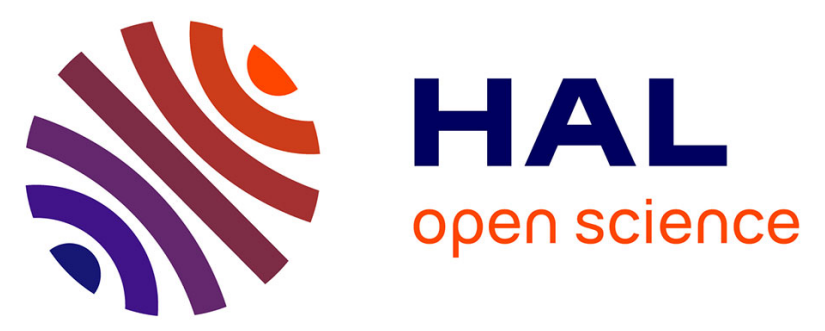

\title{
Tuning the Electrochemistry of Free-Base Porphyrins in Acidic Nonaqueous Media: Influence of Solvent, Supporting Electrolyte and Ring Substituents
}

Yan Cui, Lihan Zeng, Yuanyuan Fang, Jialiang M Zhu, Charles H. Devillers, Dominique Lucas, Nicolas Desbois, Claude P Gros, Karl M Kadish

\section{To cite this version:}

Yan Cui, Lihan Zeng, Yuanyuan Fang, Jialiang M Zhu, Charles H. Devillers, et al.. Tuning the Electrochemistry of Free-Base Porphyrins in Acidic Nonaqueous Media: Influence of Solvent, Supporting Electrolyte and Ring Substituents. ChemElectroChem, 2016, 3 (2), pp.228-241. 10.1002/celc.201500496 . hal-03471728

\section{HAL Id: hal-03471728 \\ https://hal.science/hal-03471728}

Submitted on 8 Dec 2021

HAL is a multi-disciplinary open access archive for the deposit and dissemination of scientific research documents, whether they are published or not. The documents may come from teaching and research institutions in France or abroad, or from public or private research centers.
L'archive ouverte pluridisciplinaire HAL, est destinée au dépôt et à la diffusion de documents scientifiques de niveau recherche, publiés ou non, émanant des établissements d'enseignement et de recherche français ou étrangers, des laboratoires publics ou privés. 


\title{
Tuning the Electrochemistry of Free-Base Porphyrins in Acidic Nonaqueous Media: Influence of Solvent, Supporting Electrolyte and Ring Substituents
}

\author{
Yan Cui, ${ }^{[a]}$ Lihan Zeng, ${ }^{[a]}$ Yuanyuan Fang, ${ }^{[a, b]}$ Jialiang Zhu, ${ }^{[a]}$ Charles H. Devillers, ${ }^{[c]}$ Dominique Lucas, ${ }^{[c]}$ \\ Nicolas Desbois, ${ }^{[\mathrm{c}]}$ Claude P. Gros, ${ }^{*[\mathrm{c}]}$ Karl M. Kadish ${ }^{\star[a]}$
}

\begin{abstract}
A detailed study of reduction potentials, electroreduction mechanisms and acid-base chemistry was carried out on two series of free-base porphyrins in nonaqueous media. The first series is represented by four $\beta$-pyrrole substituted tetraphenylporphyrin (TPP) derivatives, two of which are planar and two of which are nonplanar in their non-protonated form. The second comprises porphyrins with 0-4 meso-phenyl groups on the macrocycle. Equilibrium constants for conversion of each neutral porphyrin to its diprotic $\left[\mathrm{H}_{4} \mathrm{P}\right]^{2+}$ form were determined and the electrochemistry was then elucidated as a function of: (i) type of nonaqueous solvent, (ii) anion of supporting electrolyte, (iii) porphyrin ring substituents and (iv) concentration of acid added to solution. Spectroelectrochemistry was used to characterize absorption spectra of each electroreduced species and, when combined with results of the above studies, improves significantly our ability to tune redox reactivity of these type compounds.
\end{abstract}

\section{Introduction}

Studies of porphyrins and porphyrin analogues have long attracted the attention of chemists, biochemists and material scientists due to their biological relevance and their use as materials in a number of applications. ${ }^{[1,2]}$ All porphyrins can be oxidized or reduced in a number of steps, ${ }^{[3]}$ with the overall electrochemical behavior and redox potentials depending upon a number of factors, the most important of which are the type and oxidation state of the central metal ion, the solution conditions, the type, location and number of substituents on the porphyrin and the type and number of axial ligands in the case of derivatives with metal ions able to bind axial ligands. ${ }^{[4]}$

One key difference between the electrochemistry of free-base porphyrins and the related metalloporphyrins containing $+2,+3$ or +4 central metal ions is the presence of homogenous chemical reactions that follow or proceed electron transfers of

[a] Dr.Y. Cui, L. Zeng, Dr. Y. Fang, J. Zhu, Prof. K. M. Kadish Department of Chemistry, University of Houston Houston, TX 77204-5003 (USA)

Fax: (+1) 713-743-2745

E-mail: kkadish@uh.edu

[b] Dr. Y. Fang

Department of Chemistry and Chemical Engineering Jiangsu University

Zhenjiang, Jiangsu, 212013, China

[c] Dr. C. H. Devillers, Dr. N. Desbois, Prof. D. Lucas, Prof. C. P. Gros Université de Bourgogne, ICMUB UMR6302, CNRS

9 Avenue Alain Savary, BP 47870, 21078 Dijon Cedex (France) E-mail: claude.gros@u-bourgogne.fr

Supporting information for this article is given via a link at the end of the document. the free-base derivatives and lead to irreversible redox processes on the cyclic voltammetry timescale. These chemical reactions are related, in part, to the planarity of the porphyrin macrocycle ${ }^{[5]}$ and in part to the solution conditions, ${ }^{[3,4]}$ and often involve the loss or gain of protons leading to derivatives which are themselves electroactive and subject to additional coupled protonation/deprotonation reactions at the four core nitrogens, as well as proton addition to the $\pi$-ring system of the macrocycle ${ }^{[6-9]}$ following electroreduction.

The four central nitrogen atoms of a free-base porphyrin are able to accept one or two additional protons to produce protonated species of the type $\left[\mathrm{H}_{3} \mathrm{P}\right]^{+}$and $\left[\mathrm{H}_{4} \mathrm{P}\right]^{2+}[5,10-13]$ and these reactions have been examined in both aqueous and nonaqueous media as well as in mixed organic-aqueous solvents. ${ }^{[5}$, $11,14-18]$

The diprotonated free-base porphyrins $\mathrm{H}_{4} \mathrm{P}^{2+}$ can also be associated with two anions which will ion-pair to the central $\mathrm{NH}^{+}$groups in a near-symmetrical manner above and below the plane of the porphyrin macrocycle. ${ }^{[18,19]}$ These compounds are then represented as $\mathrm{H}_{4} \mathrm{P}(\mathrm{X})_{2}$, where $\mathrm{X}=\mathrm{F}^{-}, \mathrm{Cl}^{-}, \mathrm{Br}^{-}, \mathrm{I}^{-}$or $\mathrm{PF}_{6}{ }^{-[12}$, ${ }^{19-22]}$ Previous studies on interactions of diprotonated porphyrins with anions have focused in large part on structural aspects, ${ }^{[12}$, 19] the relationships between hydrogen-bond formation and the photophysical properties of the ion-paired diprotonated compounds, ${ }^{[23,}{ }^{24]}$ or the assembly properties of the compounds for applications in smart soft nanomaterials for data storage and processing, chiral sensing, optobioelectronics, chiroptical devices and catalysis. ${ }^{[17,25-30]}$ However, to our knowledge, there have been no systematic investigations which have focused on the interacting effects of anions, solvent and porphyrin structures on the protonation, electrochemistry and spectroscopic properties of the diprotonic free-base porphyrins during or after electroreduction in nonaqueous media.

This is investigated in the current manuscript, where the reduction potentials, electroreduction mechanisms and acidbase chemistry are examined for two related series of free-base tetraphenylporphyrins whose structures are shown in Schemes 1 and 2. The first group of compounds (Scheme 1) is represented by four $\beta$-pyrrole substituted TPP derivatives, two of which are planar and two of which are nonplanar in their initial non-protonated form. ${ }^{[31-34]}$ The second (Scheme 2) is comprised of porphyrins with 0-4 meso-phenyl groups on the macrocycle.

Equilibrium constants for the conversion of each free-base derivative (represented by $\mathrm{H}_{2} \mathrm{P}$ ) to its diprotic $\left[\mathrm{H}_{4} \mathrm{P}\right]^{2+}$ form are determined in the present paper by spectroscopic methods and the electrochemistry of $\left[\mathrm{H}_{4} \mathrm{P}\right]^{2+}$ is elucidated as a function of the following four parameters: (i) type of nonaqueous solvent, (ii) type of supporting electrolyte, (iii) substituents on the porphyrin macrocycle and (iv) concentration of trifluoroacetic acid (TFA) added to solution. Special emphasis is placed on $\left[\mathrm{H}_{4} \mathrm{TPP}\right]^{2+}$ whose electrochemistry was recently reported in acidic 
$\mathrm{CH}_{2} \mathrm{Cl}_{2}$ containing $0.1 \mathrm{M}$ tetra- $n$-butylammonium perchlorate $\left(\mathrm{TBAClO}_{4}\right)^{[5]}$ and shown to deviate from that of other structurally related porphyrins under the same solution conditions.

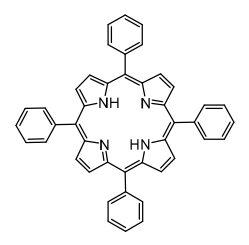

$\mathrm{H}_{2} \mathrm{TPP}$

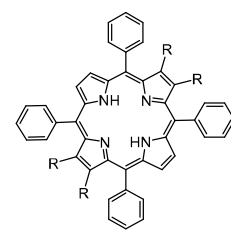

$\mathrm{R}=\mathrm{Br}, \mathrm{H}_{2} \mathrm{TPPBr}_{4}$ $R=P h, H_{2} T P P(P h)_{4}$

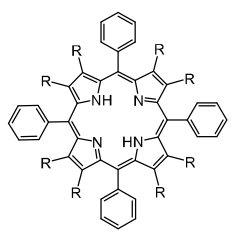

$\mathrm{R}=\mathrm{Cl}, \mathrm{H}_{2} \mathrm{TPPCl}_{8}$ $\mathrm{R}=\mathrm{Br}, \mathrm{H}_{2} \mathrm{TPPBr}_{8}$
Scheme 1.Structures of investigated free-base tetraphenylporphyrin and $\beta$ pyrrole substituted tetraphenylporphyrin derivatives.
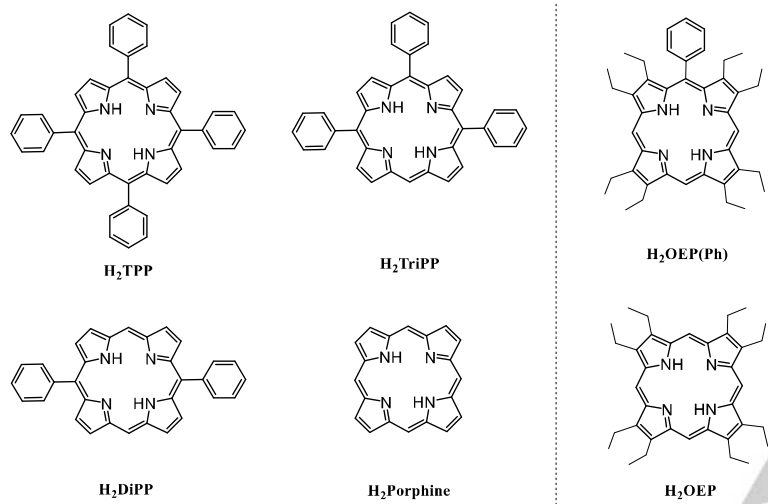

$\mathrm{H}_{2} \mathrm{OEP}(\mathbf{P h})$

Scheme 2. Structures of free-base meso-phenyl substituted derivatives.

\section{Results and Discussion}

Effects of Solvent and Supporting Electrolyte on the Reductions of $\mathrm{H}_{2}$ TPP

The electroreduction of $\mathrm{H}_{2}$ TPP was investigated in four commonly used nonaqueous solvents containing different tetra$n$-butylammonium $\left(\mathrm{TBA}^{+}\right)$salts as supporting electrolyte. The utilized solvents were dichloromethane $\left(\mathrm{CH}_{2} \mathrm{Cl}_{2}\right)$, benzonitrile (PhCN), N,N'-dimethylformamide (DMF) and dimethyl sulfoxide (DMSO) whose physical properties are given in Table S1. The supporting electrolytes were TBAX, where $\mathrm{X}=\mathrm{ClO}_{4}^{-}, \mathrm{I}^{-}, \mathrm{Br}^{-}$or $\mathrm{Cl}^{-}$. Early studies of $\mathrm{H}_{2}$ TPP in nonaqueous media ${ }^{[35]}$ had shown the presence of two stepwise one-electron transfers in solvents containing $\mathrm{TBAClO}_{4}$ and this was also observed in the present study, as illustrated by the cyclic voltammograms in Figure 1.

As seen in the Figure, the ease of $\mathrm{H}_{2}$ TPP reduction follows the order $\mathrm{CH}_{2} \mathrm{Cl}_{2}(-1.72 \mathrm{~V})<\operatorname{PhCN}(-1.67 \mathrm{~V})<\operatorname{DMF}(-1.57 \mathrm{~V})<$ DMSO $(-1.48 \mathrm{~V})$, which suggests an increasing stabilization of the singly-reduced porphyrin with increasing polarity of the solvent. This is indeed the case, as shown in Figure 2 which plots the first reduction potential (versus the $\mathrm{Fc} / \mathrm{Fc}^{+}$couple) against two commonly used solvent parameters, ${ }^{[36-39]}$ the dielectric constant, $\varepsilon_{\mathrm{r}}$, and the Dimroth-Reichardt parameter, $\mathrm{E}_{\mathrm{T}}$. Both plots in Figure 2 show a linear correlation with DMSO, DMF and $\mathrm{PhCN}$, but $\mathrm{CH}_{2} \mathrm{Cl}_{2}$ doesn't fit the dielectric constant plot and fits perfectly the plot of $E_{1 / 2}$ versus $E_{\mathrm{T}}$, with a correlation coefficient of $R^{2}=0.995$.

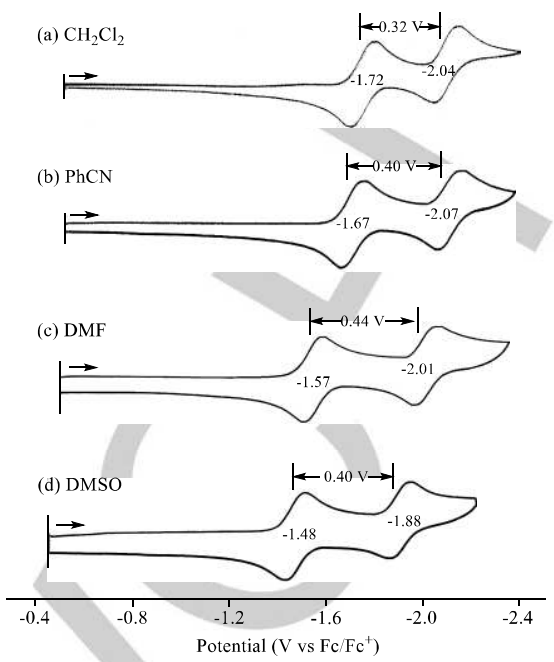

Figure 1. Effect of solvent on cyclic voltammograms of $\mathrm{H}_{2}$ TPP in (a) $\mathrm{CH}_{2} \mathrm{Cl}_{2}$, (b) $\mathrm{PhCN}$, (c) DMF and (d) DMSO containing $0.1 \mathrm{M} \mathrm{TBAClO}_{4}$. Scan rate $=0.1$ $\mathrm{V} / \mathrm{s}$.

The $240 \mathrm{mV}$ difference in $E_{1 / 2}$ between the first reduction of $\mathrm{H}_{2}$ TPP in $\mathrm{CH}_{2} \mathrm{Cl}_{2}\left(-1.72 \mathrm{~V}\right.$ vs $\left.\mathrm{Fc} / \mathrm{Fc}^{+}\right)$and DMSO $(-1.48 \mathrm{~V}$ vs $\left.\mathrm{Fc} / \mathrm{Fc}^{+}\right)$is consistent with a strong interaction between the solvent and the electrogenerated porphyrin $\pi$-anion radical formed after the addition of one electron but the solvent can also interact with the porphyrin in its neutral unreduced form and this can often be detected by changes in the position of absorption bands for the neutral compound prior to electroreduction. In order to examine this possibility, the spectrum of $\mathrm{H}_{2}$ TPP was measured in the four solvents with and without $0.1 \mathrm{M} \mathrm{TBAClO}_{4}$ which was used as supporting electrolyte as well as in $\mathrm{CH}_{2} \mathrm{Cl}_{2}$ containing $0.1 \mathrm{M}$ TBAX where $X=\mathrm{Cl}^{-}, \mathrm{Br}^{-}, \mathrm{I}^{-}$or $\mathrm{ClO}_{4}^{-}$. An example of the UV/Vis spectra of $\mathrm{H}_{2}$ TPP in $\mathrm{CH}_{2} \mathrm{Cl}_{2}$ and $\mathrm{PhCN}$ without supporting electrolyte is illustrated in Figure $\mathrm{S} 1$ and a summary of the data is given in Table 1.

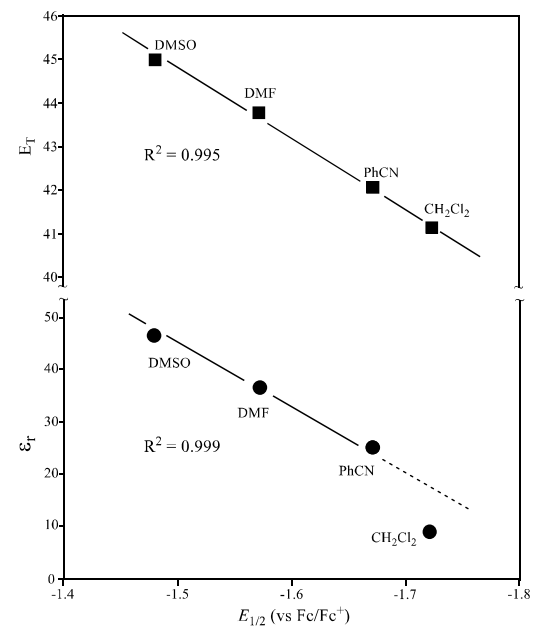

Figure 2. Plot of $\mathrm{E}_{\mathrm{T}}$ (Dimroth-Reichardt parameter) or $\varepsilon_{\mathrm{r}}$ (dielectric constants) vs. the half wave potential $\left(\mathrm{V}\right.$ vs $\mathrm{Fc} / \mathrm{Fc}^{+}$) for the first reduction of $\mathrm{H}_{2} \mathrm{TPP}$ in $\mathrm{CH}_{2} \mathrm{Cl}_{2}, \mathrm{PhCN}$, DMF and DMSO. 
Table 1. UV/Vis spectral data $\left(\lambda_{\max }, \mathrm{nm}\right)$ for neutral $\mathrm{H}_{2}$ TPP in different solvents without supporting electrolyte and in $\mathrm{CH}_{2} \mathrm{Cl}_{2}$ containing different $0.1 \mathrm{M}$ TBAX salts.

\begin{tabular}{|c|c|c|c|c|c|c|c|}
\hline Solvent & $\mathrm{AN}^{[\mathrm{a}]}$ & $\begin{array}{l}\text { Anion } \\
(0.1 \mathrm{M})\end{array}$ & $\begin{array}{l}\lambda / \mathrm{nm}(\log \varepsilon) \\
\text { Soret band }\end{array}$ & $\mathrm{Q}$ bands & & & \\
\hline $\mathrm{PhCN}$ & 15.5 & none & $423(5.47)$ & $516(4.13)$ & $552(3.83)$ & $593(3.08)$ & 649 (3.06) \\
\hline DMF & 16.0 & none & $418(5.41)$ & $515(4.07)$ & 549 (3.69) & $591(3.51)$ & $646(3.40)$ \\
\hline $\mathrm{CH}_{2} \mathrm{Cl}_{2}$ & 20.4 & none & $418(5.41)$ & $515(4.15)$ & $549(3.92)$ & $591(3.86)$ & 647 (3.86) \\
\hline \multirow[t]{4}{*}{$\mathrm{CH}_{2} \mathrm{Cl}_{2}$} & 20.4 & TBACI & $418(5.41)$ & $515(4.07)$ & 549 (3.77) & 591 (3.66) & 647 (3.62) \\
\hline & & $\mathrm{TBABr}$ & $418(5.40)$ & $515(4.34)$ & $549(4.19)$ & $591(4.12)$ & $647(4.06)$ \\
\hline & & TBAI & $418(5.41)$ & $515(4.04)$ & 549 (3.69) & $591(3.57)$ & 647 (3.49) \\
\hline & & $\mathrm{TBAClO}_{4}$ & $418(5.40)$ & $515(4.03)$ & 549 (3.66) & 591 (3.54) & 647 (3.45) \\
\hline
\end{tabular}

[a]AN = Gutmann solvent acceptor number taken from Ref. [39]

As seen in Table 1 and Figure S1, the shape of the UV/Vis spectrum for $\mathrm{H}_{2}$ TPP is similar in each solvent, consisting of a sharp Soret band at $418-423 \mathrm{~nm}$ and four less intense $Q$ bands from 515-649 $\mathrm{nm}$. Several correlations were examined between the band energy (in $\mathrm{cm}^{-1}$ ) and different solvent parameters and the best fit was found to exist between the acceptor number of the solvent (AN) and the measured wavelength of the porphyrin Soret band in $\mathrm{CH}_{2} \mathrm{Cl}_{2}$, DMSO and $\mathrm{PhCN}$ (but not DMF) (see Figure S2).

Anions are known to bind to the central protons of expanded free-base porphyrins and related macrocycles in their neutral form ${ }^{[40-47]}$ and one of our interests in the present study was to investigate how changes in the supporting electrolyte anion would affect both the measured reduction potentials and the stability of the porphyrin products formed in the first and/or second reduction on the electrochemical and spectroelectrochemical timescale. Examples of the electrochemical data are given in Figures S3 and S4 which illustrate cyclic voltammograms of $\mathrm{H}_{2}$ TPP in the four solvents containing TBAX, where $\mathrm{X}=\mathrm{Cl}^{-}, \mathrm{Br}, \mathrm{I}^{-}$and $\mathrm{ClO}_{4}^{-}$.

As seen in Figure $\mathrm{S} 3$, the first one-electron reduction in $\mathrm{CH}_{2} \mathrm{Cl}_{2}$ containing TBACl $(-1.11 \mathrm{~V}$ vs. SCE) or TBABr $(-1.12 \mathrm{~V})$ is easier by $80-100 \mathrm{mV}$ than the first one-electron reduction of the porphyrin in the same solvent containing TBAI $(-1.19 \mathrm{~V})$ or $\mathrm{TBAClO}_{4}(-1.21 \mathrm{~V})$. A similar trend in $E_{1 / 2}$ with change of supporting electrolyte is seen in DMSO (Figure S4) and, although the difference in half-wave potentials between the solution conditions is not large, the most difficult reduction in DMSO again seems to occur when using the $\mathrm{TBAClO}_{4}$ salt assupporting electrolyte $\left(E_{1 / 2}=-1.03 \mathrm{~V}\right.$ vs. SCE). More importantly, the difference in reduction half-wave potentials, when measured vs. SCE, might seem to suggest an interaction of $\mathrm{Cl}^{-}$and $\mathrm{Br}$ with the singly reduced porphyrin in the nonbonding solvent $\mathrm{CH}_{2} \mathrm{Cl}_{2}$. However, when the reduction potentials are measured vs. the $\mathrm{Fc} / \mathrm{Fc}^{+}$couple used as an internal standard, no significant differences of $E_{1 / 2}$ are observed with changes in the anion of the supporting electrolyte in any of the four solvents. These reduction potentials of $\mathrm{H}_{2}$ TPP vs. $\mathrm{Fc} / \mathrm{Fc}^{+}$are listed in the last two columns of Table 2, and are identical to each other in all four solvents within the experimental error of the measurements $( \pm 10 \mathrm{mV})$. This lack of anion effect on the thermodynamic $E_{1 / 2}$ for reduction can be interpreted in terms of the four anions acting to produce an equal stabilization of the neutral and singly reduced forms of the porphyrin (according to the Nernst equation). However, an alternate interpretation is that there is no interaction at all between the supporting electrolyte anions and the neutral or singly reduced forms of the compounds which are characterized as porphyrin $\pi$-anion radicals after the addition of one electron to the conjugated macrocycle.

This latter condition seems to be the case as indicated by UV/Vis spectra of the neutral porphyrin in $\mathrm{CH}_{2} \mathrm{Cl}_{2}$ containing the four TBAX salts. The absorption bands in $\mathrm{CH}_{2} \mathrm{Cl}_{2}$ containing 0.1 $M$ of each TBAX salt are given in Table 1 and are identical to each other, independent of the anion. The lack of an anion effect on both the UV/Vis spectrum of $\mathrm{H}_{2}$ TPP in $\mathrm{CH}_{2} \mathrm{Cl}_{2}$ and the reduction potentials of the porphyrin in $\mathrm{CH}_{2} \mathrm{Cl}_{2}$, containing $0.1 \mathrm{M}$ TBAX when measured vs. $\mathrm{Fc} / \mathrm{FC}^{+}$is not what occurs for the diprotonated porphyrins $\left[\mathrm{H}_{4} \mathrm{TPP}\right]^{2+}$ in the acidic solvents and this is described in the following sections of the manuscript.

Effects of Solvent and Supporting Electrolyte on the Protonation Constants of $\mathrm{H}_{2}$ TPP and UV/Vis Spectra of $\left[\mathrm{H}_{4} \mathrm{TPP}\right]^{2+}$

The conversion of $\mathrm{H}_{2}$ TPP to its diprotonated $\left[\mathrm{H}_{4} \mathrm{TPP}\right]^{2+}$ form can be monitored by UV/Vis spectroscopy and proceeds in a single step, as written in Eq 1. ${ }^{[5,12,18,48]}$

$$
\mathrm{H}_{2} \mathrm{TPP}+2 \mathrm{H}^{+} \rightleftharpoons\left[\mathrm{H}_{4} \mathrm{TPP}\right]^{2+}
$$

A $\log \beta_{2}=9.96$ was earlier reported for $\mathrm{H}_{2}$ TPP in $\mathrm{CH}_{2} \mathrm{Cl}_{2}{ }^{[5]}$ and a smaller value of 9.10 was measured for the same reaction in the current study under the electrochemical conditions of $\mathrm{CH}_{2} \mathrm{Cl}_{2}$ containing $0.1 \mathrm{M} \mathrm{TBAClO}_{4}$ as supporting electrolyte where the product of the titration is more correctly represented as $\mathrm{H}_{4} \operatorname{TPP}\left(\mathrm{ClO}_{4}\right)_{2}$. Measurements of $\log \beta_{2}$ were also carried out for $\mathrm{H}_{2}$ TPP in $\mathrm{CH}_{2} \mathrm{Cl}_{2}$ containing the TBAI, TBABr and TBACl salts and here the final product of the titration would be represented as $\mathrm{H}_{4} \operatorname{TPP}(\mathrm{X})_{2}$, where $\mathrm{X}=\mathrm{I}^{-}, \mathrm{Br}^{-}$or $\mathrm{Cl}^{-}$. Examples of spectral changes monitored during these titrations are illustrated in Figure 3 and a summary of the formation constants for proton addition, $\log \beta_{2}$, andUV/Vis spectral data for the final ion-paired diprotic porphyrin product is given in Table 3 .

Thediprotonated free-base tetraphenylporphyrin is characterized by two major absorptions, whose exact position will depend upon both the utilized solvent and the presence or absence of added TBAX. In the absence of supporting electrolyte the Soret band maxima ranges from $441-445 \mathrm{~nm}$ while the $Q$ band is located at $\lambda_{\max }=656-663 \mathrm{~nm}$. There is clearly a solvent effect on the $\left[\mathrm{H}_{4} \mathrm{TPP}\right]^{2+}$ absorption spectra and there is also an effect of 
anion as shown by the data in $\mathrm{CH}_{2} \mathrm{Cl}_{2}$ containing TBAX where the Soret band maximum ranges from $443-453 \mathrm{~nm}$ and the $\mathrm{Q}$ band from 659-679 $\mathrm{nm}$. Despite the largedifference in the position of the peak maxima under the different solution conditions, there is no obvious trend in the positionof $\lambda_{\max }$ with change in the TBAX anion of the salt in solution. For example, the Soret band maximum of $\left[\mathrm{H}_{4} \mathrm{TPP}\right]^{2+}$ follows the order: $\mathrm{Br}^{-}(453$ $\mathrm{nm})>\mathrm{Cl}^{-}(449 \mathrm{~nm})>\mathrm{I}^{-}(447 \mathrm{~nm})>\mathrm{ClO}_{4}^{-}(441 \mathrm{~nm})$, but this is not the relative order of the $Q$ band position which ranges from 659$679 \mathrm{~nm}$ and follows the order: $\mathrm{I}^{-}(679 \mathrm{~nm})>\mathrm{Br}^{-}(671 \mathrm{~nm})>\mathrm{Cl}^{-}$ $(666 \mathrm{~nm})>\mathrm{ClO}_{4}^{-}(659 \mathrm{~nm})$. The $\mathrm{Q}$ band of $\mathrm{H}_{4} \operatorname{TPP}(\mathrm{I})_{2}$ in solutions with TBAI is not only the most red-shifted of the examined porphyrin diacids but it is also the broadest $Q$ band with the lowest intensity. This suggests a different interaction between the $\mathrm{I}^{-}$anions and the diprotonated form of the porphyrin, as compared to the case of $\left[\mathrm{H}_{4} \mathrm{TPP}\right]^{2+}$ in solutions with $\mathrm{Cl}^{-}, \mathrm{Br}$, or $\mathrm{ClO}_{4}{ }^{-}$. The spectrum of $\mathrm{H}_{4} \operatorname{TPP}(\mathrm{I})_{2}$ has been discussed in the literature by the groups of Rosa, Ricciardi, Baerends and Scolaro ${ }^{[12,19]}$ who examined the effects of structure and counterions on the optical properties of $\mathrm{H}_{4} \operatorname{TPP}(\mathrm{X})_{2}$, where $\mathrm{X}=\mathrm{F}^{-}$ $\mathrm{Cl}^{-}, \mathrm{Br}$ or $\mathrm{I}^{-}$.

The $\log \beta_{2}$ values for protonation of $\mathrm{H}_{2}$ TPP in $\mathrm{CH}_{2} \mathrm{Cl}_{2}$ containing $0.1 \mathrm{M}$ TBAX ranges from 9.10 to 9.96 and roughly correlates with the position of the $Q$ band under the same solution conditions. This correlation is shown in Figure S5.

More significant variations in the measured $\log \beta_{2}$ values for protonation of $\mathrm{H}_{2}$ TPP, are seen upon changing the solvent from
$\mathrm{CH}_{2} \mathrm{Cl}_{2}$ to $\mathrm{PhCN}$ and then to DMSO or DMF. The relevant spectral changes during the titrations with TFA are illustrated in Figure $\mathrm{S} 6$ and the absorption maxima and measured formation constants are summarized in Table 3.

As seen in the figure and table, the spectrum of the final diprotonated porphyrin product is almost the same in the different solvents, but the values of $\log \beta_{2}$ have decreasedsubstantially in DMSO and DMF where large quantities of acid are needed to accomplish the protonation. $\mathrm{A}$ good correlation is seen between the $\log \beta_{2}$ values in $\mathrm{CH}_{2} \mathrm{Cl}_{2}$, $\mathrm{PhCN}$ and DMSO and two solvent parameters, the dielectric constant $\varepsilon_{\mathrm{r}}$ and donor number (DN) (see Figure S7). The smallest value of $\log \beta_{2}=0.39$ is obtained in DMF. This value is included in Figure S7 but does not fit the good correlation observed for other three solvents.

Effects of Solvent and Supporting Electrolyte on the Electrochemistry of $\left[\mathrm{H}_{4} \mathrm{TPP}\right]^{2+}$

The conversion of $\mathrm{H}_{2}$ TPP to its diprotonated form was electrochemically monitored during a TFA titration of the porphyrin in three different solvents $\left(\mathrm{CH}_{2} \mathrm{Cl}_{2}\right.$, DMF and DMSO) containing $0.1 \mathrm{M} \mathrm{TBAClO}_{4}$ as well as in $\mathrm{CH}_{2} \mathrm{Cl}_{2}$ containing $0.1 \mathrm{M}$ of the different TBAX supporting electrolytes. Examples of the cyclic voltammograms obtained at various points of the titration

Table 2. Half-wave potentials (V vs SCE) for reduction of $\mathrm{H}_{2}$ TPP in solvents containing different supporting electrolytes at a concentration of $0.1 \mathrm{M}$.

\begin{tabular}{|c|c|c|c|c|c|c|c|c|c|c|}
\hline \multirow[t]{2}{*}{ Solvent } & \multirow{2}{*}{$\begin{array}{c}\text { Dielectric } \\
\text { Constant }\left(\varepsilon_{\mathrm{r}}\right)\end{array}$} & \multirow[t]{2}{*}{$\mathrm{E}_{\mathrm{T}^{[\mathrm{a}]}}$} & \multirow[t]{2}{*}{$D N^{[b]}$} & \multirow[t]{2}{*}{ Electrolyte } & \multicolumn{2}{|c|}{$\begin{array}{c}E_{1 / 2} \\
\text { (V vs SCE) }\end{array}$} & \multirow{2}{*}{$\begin{array}{l}\Delta \mathrm{E} \\
(\mathrm{V})\end{array}$} & \multirow{2}{*}{$\begin{array}{c}{\mathrm{Fc} / \mathrm{Fc}^{+}} \\
(\mathrm{V})\end{array}$} & \multicolumn{2}{|c|}{$\begin{array}{c}E_{1 / 2} \\
\left(\mathrm{~V} \text { vs } \mathrm{Fc} / \mathrm{Fc}^{+}\right)\end{array}$} \\
\hline & & & & & 1st & 2nd & & & 1st & 2nd \\
\hline \multirow[t]{4}{*}{$\mathrm{CH}_{2} \mathrm{Cl}_{2}$} & 8.93 & 41.1 & 0.0 & TBACl & -1.11 & -1.43 & 0.32 & 0.62 & -1.73 & -2.05 \\
\hline & & & & & -1.12 & -1.45 & 0.33 & 0.57 & -1.69 & -2.02 \\
\hline & & & & TBAI & -1.19 & -1.51 & 0.32 & NA & NA & NA \\
\hline & & & & $\mathrm{TBAClO}_{4}$ & -1.21 & -1.53 & 0.32 & 0.51 & -1.72 & -2.04 \\
\hline \multirow[t]{4}{*}{$\mathrm{PhCN}$} & 25.20 & & 11.9 & TBACI & -1.08 & -1.48 & 0.40 & 0.60 & -1.68 & -2.08 \\
\hline & & & & $\mathrm{TBABr}$ & -1.09 & -1.49 & 0.40 & 0.58 & -1.67 & -2.07 \\
\hline & & & & & -1.14 & -1.54 & 0.40 & NA & NA & NA \\
\hline & & & & $\mathrm{TBAClO}_{4}$ & -1.16 & -1.56 & 0.40 & 0.58 & -1.67 & -2.07 \\
\hline \multirow{3}{*}{ DMF } & & & & $\mathrm{TBABr}$ & -1.06 & -1.5 & 0.44 & 0.51 & -1.57 & -2.01 \\
\hline & & & & TBAI & -1.07 & -1.51 & 0.44 & NA & NA & NA \\
\hline & & & & $\mathrm{TBAClO}_{4}$ & -1.07 & -1.51 & 0.44 & 0.50 & -1.57 & -2.01 \\
\hline \multirow[t]{4}{*}{ DMSO } & 46.68 & 45 & 29.8 & TBACI & -0.99 & -1.41 & 0.42 & 0.48 & -1.47 & -1.89 \\
\hline & & & & $\mathrm{TBABr}$ & -1.00 & -1.42 & 0.42 & 0.48 & -1.48 & -1.90 \\
\hline & & & & TBAI & -1.00 & -1.42 & 0.42 & NA & NA & NA \\
\hline & & & & $\mathrm{TBAClO}_{4}$ & -1.03 & -1.43 & 0.40 & 0.45 & -1.48 & -1.88 \\
\hline
\end{tabular}

[a]E $\mathrm{E}_{\mathrm{T}}$ Dimroth-Reichardt parameter, [b]DN = Gutmann solvent donor number taken from Ref.[39] 

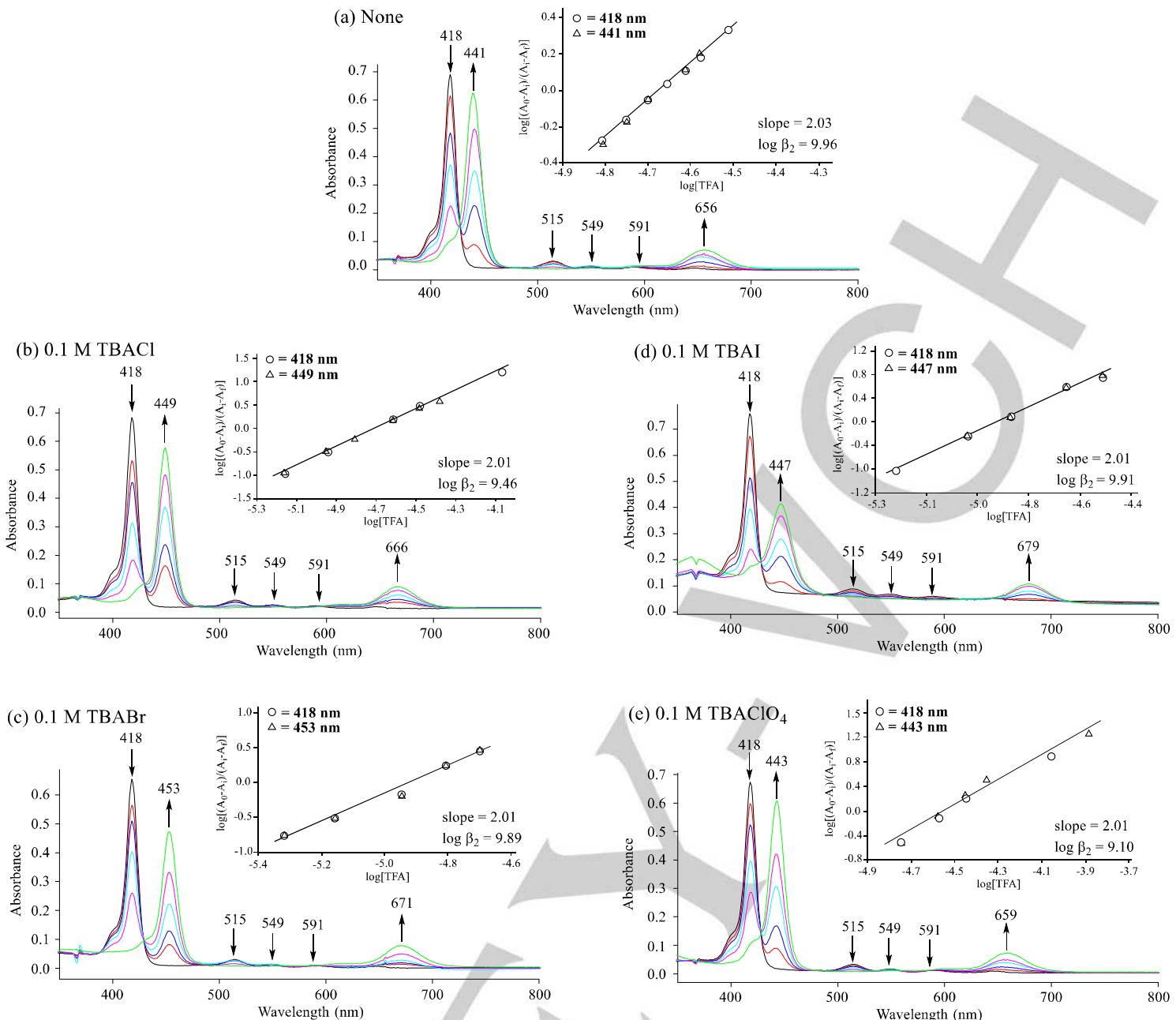

Figure 3. Effect of supporting electrolyte type on UV/Vis spectra changes of $\mathrm{H}_{2}$ TPP in $\mathrm{CH}_{2} \mathrm{Cl}_{2}$ during titration with TFA containing (a) no added salt and $0.1 \mathrm{M}$ TBAX where $\mathrm{X}$ is (b) $\mathrm{Cl}^{-}$, (c) $\mathrm{Br}^{-}$, (d) $\mathrm{I}^{-}$and (e) $\mathrm{ClO}_{4}{ }^{-}$.

Table 3. UV/Vis spectral data $\left(\lambda_{\max }, \mathrm{nm}\right)$ for $\mathrm{H}_{4} \mathrm{TPP}(\mathrm{X})_{2}$ and $\left[\mathrm{H}_{4} \mathrm{TPP}\right]^{2+}$ in

$\mathrm{CH}_{2} \mathrm{Cl}_{2}, \mathrm{PhCN}$ and DMSO containing excess TFA and differentTBAX salts.

\begin{tabular}{clccc}
\hline \multirow{2}{*}{ Solvent } & \multirow{2}{*}{$\begin{array}{c}\text { Anion, } X \\
(0.1 \mathrm{M})\end{array}$} & \multicolumn{2}{c}{$\lambda / \mathrm{nm}$} & $\log \beta_{2}$ \\
\cline { 3 - 4 } $\mathrm{CH}_{2} \mathrm{Cl}_{2}$ & $\mathrm{Cl}^{-}$ & 449 & 666 & 9.46 \\
& $\mathrm{Br}^{-}$ & 453 & 671 & 9.89 \\
& $\mathrm{I}^{-}$ & 447 & 679 & 9.91 \\
& $\mathrm{ClO}_{4}^{-}$ & 443 & 659 & 9.10 \\
& none & 441 & 656 & 9.96 \\
$\mathrm{CH}_{2} \mathrm{Cl}_{2}$ & none & 444 & 664 & 5.86 \\
$\mathrm{PhCN}^{-}$ & none & 445 & 663 & 1.14 \\
$\mathrm{DMSO}$ & none & 443 & 661 & 0.39 \\
$\mathrm{DMF}$ & & &
\end{tabular}

in $\mathrm{CH}_{2} \mathrm{Cl}_{2}$ containing $0.1 \mathrm{M} \mathrm{TBAClO}$ are shown in Figure 4. In the absence of TFA, the initial free-base porphyrin undergoes two reversible one-electron reductions at -1.21 and $-1.53 \mathrm{~V}$ to give a porphyrin $\pi$-anion radical and dianion, respectively. Two reduction peaks are also seen in acidic $\mathrm{CH}_{2} \mathrm{Cl}_{2}$ solutions, butunder these conditions, the first process involves an overall two electron addition to the conjugated macrocycle and the second is assigned to reduction of a product generated at the electrode surface via a chemical reaction involving the doubly reduced porphyrin as described on the following pages.

The conversion of $\mathrm{H}_{2}$ TPP to $\left[\mathrm{H}_{4}\right.$ TPP] ${ }^{2+}$ proceeds as shown in Eq. 2 and this diprotonated porphyrin species in $\mathrm{CH}_{2} \mathrm{Cl}_{2}, 0.1 \mathrm{M}$ $\mathrm{TBAClO}_{4}$ is then reduced in two overlapping one-electron transfer steps at $E_{\mathrm{p}} \approx-0.49 \mathrm{~V}$ (for a scan rate of $0.1 \mathrm{~V} / \mathrm{s}$ ) to give a transient and highly reactive doubly reduced porphyrin at the electrode surface. The reactant in Eq. 2 is represented as $\left[\mathrm{H}_{4} \mathrm{TPP}\right]^{2+}$ but mostly likely exists as $\mathrm{H}_{4} \operatorname{TPP}\left(\mathrm{ClO}_{4}\right)_{2}$.

$$
\left[\mathrm{H}_{4} \mathrm{TPP}^{2+} \stackrel{\mathrm{e}^{-}}{\rightleftharpoons}\left[\mathrm{H}_{4} \mathrm{TPP}\right]^{+} \stackrel{\mathrm{e}^{-}}{\rightleftharpoons}\left[\mathrm{H}_{4} \mathrm{TPP}\right]^{0}\right.
$$




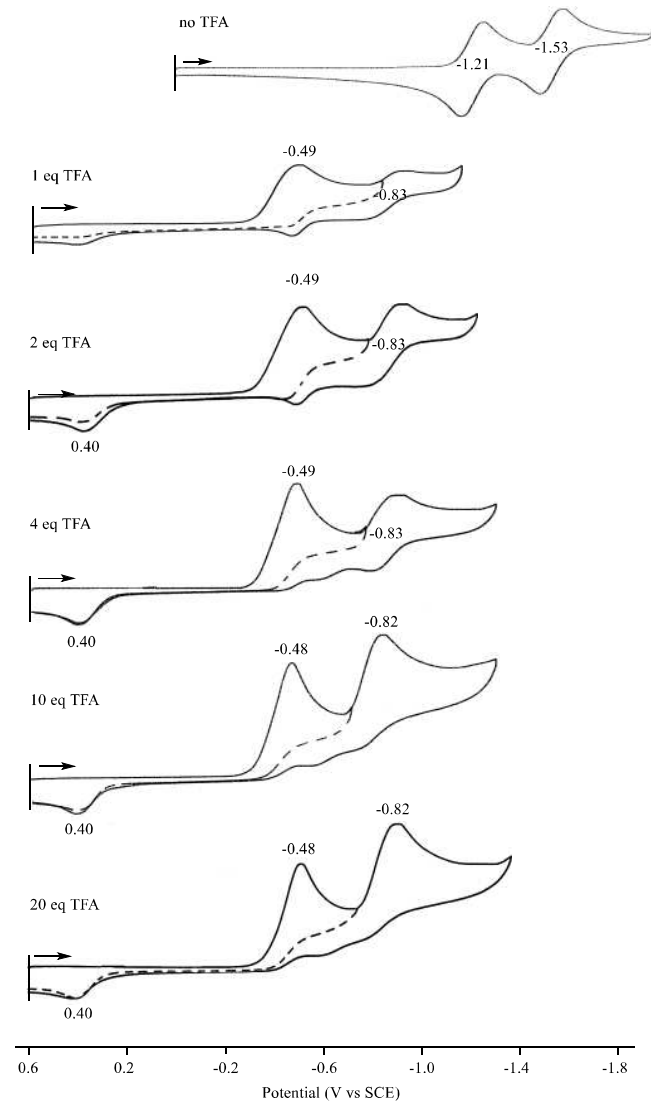

Figure 4. Cyclic voltammograms of $\mathrm{H}_{2} \operatorname{TPP}\left(\sim 10^{-4} \mathrm{M}\right)$ in $\mathrm{CH}_{2} \mathrm{Cl}_{2}$ containing 0.1 $\mathrm{M} \mathrm{TBAClO}$ during titration with TFA. Scan rate $=0.1 \mathrm{~V} / \mathrm{s}$.

Evidence for the addition of two overlapping one-electron transfers in the first reduction of $\left[\mathrm{H}_{4} \mathrm{TPP}\right]^{2+}$ is given by comparing the peak currents for the process at $E_{\mathrm{p}} \approx-0.49 \mathrm{~V}$ at different acid concentrations to the peak current for reduction of the initial compound at $E_{1 / 2}=-1.21 \mathrm{~V}$ in the absence of acid. This ratio of peak currents is given by $\mathrm{i} / \mathrm{i}_{0}$ and, when plotted vs. the $[T F A] /\left[\mathrm{H}_{2} \mathrm{TPP}\right]$ ratio (Figure $\mathrm{S} 8$ ), clearly shows a doubling of the current for reduction of $\left[\mathrm{H}_{4} \mathrm{TPP}\right]^{2+}$ as compared to the current for reduction of $\mathrm{H}_{2}$ TPP. This is consistent with two overlapping one electron transfers at the same potential (an electrochemical EE mechanism) as opposed to a single step, two electron transfer where the current for reduction of $\left[\mathrm{H}_{4} \mathrm{TPP}\right]^{2+}$ would be proportional to $\mathrm{n}^{3 / 2}$ and would thus be 2.83 times higher for $\left[\mathrm{H}_{4} \mathrm{TPP}\right]^{2+}$ than for $\mathrm{H}_{2}$ TPP. ${ }^{[49]}$

There is no change in the number of protons on the central nitrogen atoms of $\left[\mathrm{H}_{4} \mathrm{TPP}\right]^{2+}$ during the timescale of the first overall two electron reduction of this compound in $\mathrm{CH}_{2} \mathrm{Cl}_{2}, 0.1 \mathrm{M}$ $\mathrm{TBAClO}_{4}$, as evidenced by the fact that the peak potential remained invariant as the acid concentration in solution was increased from 1 to 20 equivalents TFA (see Figure 4). This would not be the case if a gain or loss of protons were to occur on the electrochemical timescale where the peak potential might then be expected to shift by 60 or $120 \mathrm{mV}$ for each tenfold change in $\left[\mathrm{H}^{+}\right] .^{[49]}$

As indicated above, the first reduction of $\left[\mathrm{H}_{4} \mathrm{TPP}\right]^{2+}$, at $=-0.49$ $\mathrm{V}$ in the acidic $\mathrm{CH}_{2} \mathrm{Cl}_{2}$ solution, corresponds to an overall twoelectron reduction of the conjugated macrocycle and the second process at $=-0.83 \mathrm{~V}$ in Figure 4 corresponds to the electroreduction of a phlorin anion which is generated at the electrode surface after reaction of the electrogenerated porphyrin dianion with protons in the solution. The currentvoltage curves for reduction of $\left[\mathrm{H}_{4} \mathrm{TPP}\right]^{2+}$ in the acidic $\mathrm{CH}_{2} \mathrm{Cl}_{2}$ solutions of Figure 4 are similar to $\mathrm{CV}$ data described by Wilson and Peychal-Heiling for the reduction of $\mathrm{H}_{2}$ TPP in DMF containing $0.1 \mathrm{M} \mathrm{TEAP}^{[6]}$ and the proposed mechanism is given in Scheme 3 where the second reversible reduction at $E_{1 / 2}=$ $0.83 \mathrm{~V}$ and first irreversible reoxidation at $E_{\mathrm{p}}=0.40 \mathrm{~V}$ are both attributed to electrode reactions of a protonated phlorin anion which is generated at the electrode surface after formation of the doubly reduced $\left[\mathrm{H}_{4} \mathrm{TPP}\right]^{0}$ dianion.

The effect of the TBAX supporting electrolyte on the electrochemistry of $\left[\mathrm{H}_{4} \mathrm{TPP}\right]^{2+}$ (or $\left.\mathrm{H}_{4} \mathrm{TPP}(\mathrm{X})_{2}\right)$ is shown in Figure 5 which compares cyclic voltammograms of $10^{-4} \mathrm{M} \mathrm{H}_{2}$ TPP in $\mathrm{CH}_{2} \mathrm{Cl}_{2}$ solutions containing 4.0 equivalents of TFA and $0.1 \mathrm{M}$ TBAX. The voltammograms recorded with TBACl, TBAI or $\mathrm{TBABr}$ as supporting electrolyte are similar to those recorded in solutions with $\mathrm{TBAClO}_{4}$ in that each diprotic porphyrin undergoes an initial two-electron reduction followed by formation of an electroactive phlorin anion at the surface of the electrode. The homogenously generated phlorin anion can then be reversibly reduced by one electron at $E_{1 / 2}$ values of -0.76 to $0.83 \mathrm{~V}$ (see dashed lines in Figure 5 ) or it can be irreversibly reoxidized at a peak potential of 0.26 to $0.40 \mathrm{~V}$ (for a scan rate of $0.1 \mathrm{~V} / \mathrm{s}$ ) to give back the initial compound.

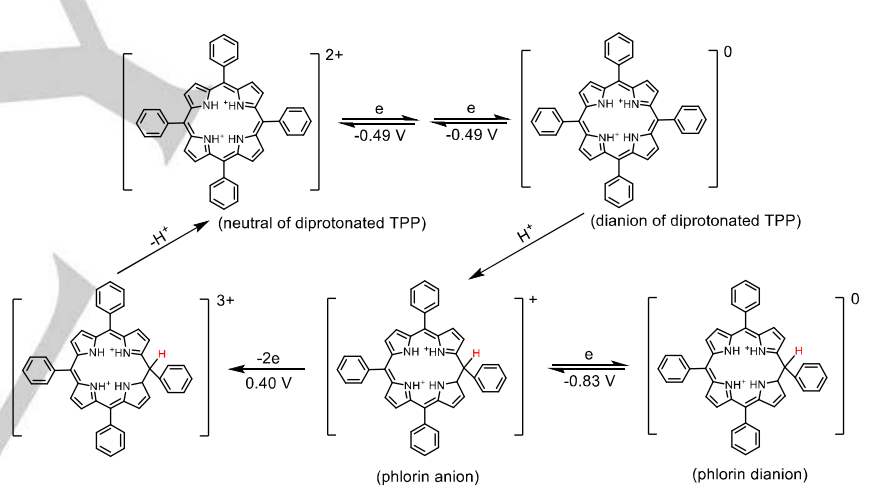

Scheme 3. Proposed mechanism for reduction of $\left[\mathrm{H}_{4} \mathrm{TPP}\right]^{2+}$ in $\mathrm{CH}_{2} \mathrm{Cl}_{2}$ containing $0.1 \mathrm{M} \mathrm{TBAClO}$. The listed potentials are taken from voltammograms in Figure 4.

The most significant difference in redox behavior of the four $\mathrm{H}_{4} \mathrm{TPP}(\mathrm{X})_{2}$ complexes in $\mathrm{CH}_{2} \mathrm{Cl}_{2}$ containing $0.1 \mathrm{M}$ TBAX is that half-wave potentials for the first two one-electron additions are overlapped in potential when using $\mathrm{TBAClO}_{4}$ as the supporting electrolyte but separated by $120-130 \mathrm{mV}$ in the $\mathrm{CH}_{2} \mathrm{Cl}_{2}$ solutions containing $0.1 \mathrm{M} \mathrm{TBACl}$ or TBABr (Figure 5). This separation in potential leads to a reversible first reduction in the solutions with $\mathrm{Cl}^{-}$or $\mathrm{Br}^{-}$since the chemical reaction leading to formation of the phlorin anion is only observed after the addition of a second electron to the porphyrin conjugated $\pi$-ring system. The two reductions of $\mathrm{H}_{2}$ TPP in $\mathrm{CH}_{2} \mathrm{Cl}_{2}$ containing TBAl are also separated in potential by about $100 \mathrm{mV}$ and a quasi-reversible first reduction is observed at $E_{1 / 2}=-0.43 \mathrm{~V}$. However, formation of the phlorin anion is rapid after the second electron addition in the TBAI solution and a totally reversible initial reduction of the porphyrin cannot be observed under these solution conditions. 

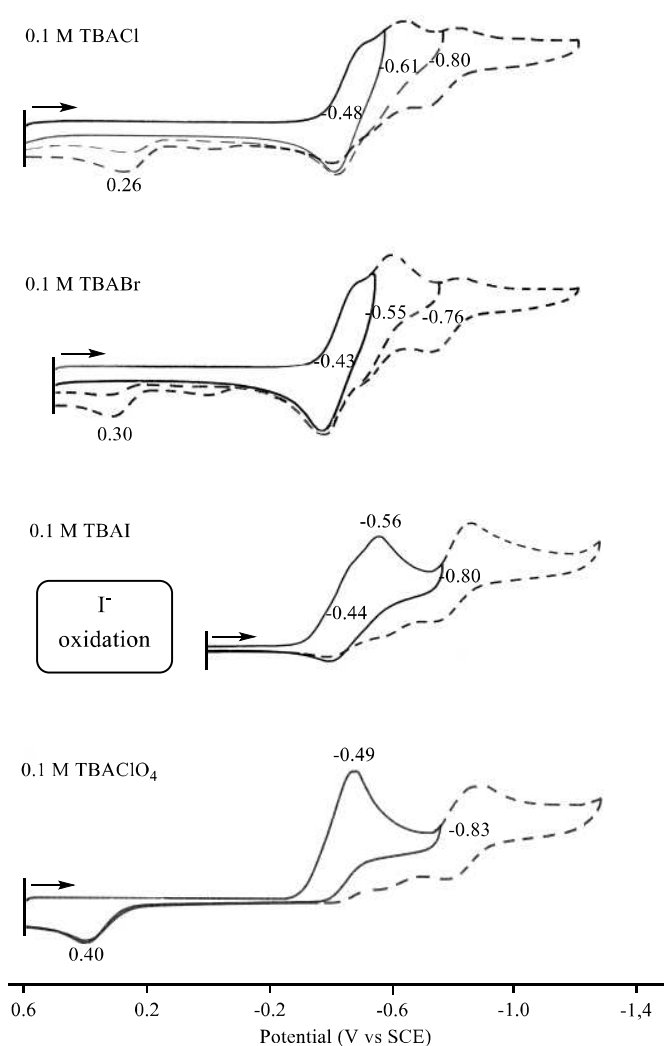

Figure 5. Cyclic voltammograms of $\mathrm{H}_{2} \mathrm{TPP}\left(\sim 10^{-4} \mathrm{M}\right)$ in $\mathrm{CH}_{2} \mathrm{Cl}_{2}$ containing 4 eq TFA and $0.1 \mathrm{M} \mathrm{TBACl}, \mathrm{TBABr}$, TBAl and $\mathrm{TBAClO}_{4}$ different supporting electrolytes.

A splitting of the two overlapping redox reactions of $\mathrm{H}_{2} \operatorname{TPP}(\mathrm{X})_{2}$ into two well resolved one-electron transfer processes occurs not only in solutions of $\mathrm{CH}_{2} \mathrm{Cl}_{2}$ containing $\mathrm{Cl}^{-}$, $\mathrm{Br}^{-}$, and in part $\mathrm{I}^{-}$, but also in DMF containing high acid concentrations and $0.1 \mathrm{M} \mathrm{ClO}_{4}^{-}$from the $\mathrm{TBAClO}_{4}$ supporting electrolyte. This is illustrated in Figure S9 where the first two one-electron reductions of $10^{-4} \mathrm{M} \mathrm{H}_{2}$ TPP in DMF, $0.1 \mathrm{M}$ $\mathrm{TBAClO}_{4}$ are overlapped in potential in solutions containing up to 20 eq TFA but begin to separate from each other as the acid concentration is increased from 100 to 1000 eq TFA (corresponding to 0.01 to $0.1 \mathrm{M}$ TFA concentration).

The first one electron reduction occurs at progressively more positive potentials with increase in the acid concentration while the second electron addition occurs at an $E_{1 / 2}$ value which is independent of the acid concentration after 20 eq TFA have been added to the solution.

Two points should be noted with respect to the electrochemical data in Figure S9. The first is that the facile redox process at low TFA concentrations occurs under the application of an applied reducing potential which converts the unprotonated $\mathrm{H}_{2}$ TPP species in the bulk of the DMF solution to its more easily reducible diprotic form, $\left[\mathrm{H}_{4} \mathrm{TPP}\right]^{2+}$. The bulk conversion of $\mathrm{H}_{2}$ TPP which is reduced at $-1.07 \mathrm{~V}$ to $\left[\mathrm{H}_{4} \mathrm{TPP}\right]^{2+}$ which is reduced at $-0.40 \mathrm{~V}$ requires large quantities of TFA as indicated by the measured $\log \beta_{2}$ value of 0.39 in the DMF solvent. (Figure S6). However, the rate of conversion of $\mathrm{H}_{2}$ TPP to $\left[\mathrm{H}_{4} \mathrm{TPP}\right]^{2+}$ is extremely rapid and this facilitates a shifting of the equilibrium towards the more easily reducible species as shown in Scheme 4.

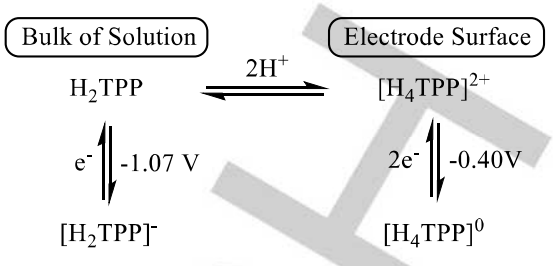

Scheme 4. Equilibrium between $\mathrm{H}_{2} \mathrm{TPP}$ and more easily reducible $\left[\mathrm{H}_{4} \mathrm{TPP}\right]^{2+}$ in the presence of an applied reducing potential.

\section{Effect of Macrocycle Structure on Reduction of Free-base $\beta$ -} Pyrrole Porphyrin Diacids

A recent publication from our laboratory described the electrochemistry for a series of planar and non-planar $\beta$-pyrrole substituted free-base porphyrins in $\mathrm{CH}_{2} \mathrm{Cl}_{2}$ containing $0.1 \mathrm{M}$ $\mathrm{TBAClO}_{4}$ and added acid in the form of TFA ${ }^{[5]}$ andfour of the porphyrins from this earlier investigation are now further characterized in the present study when dissolved in acidic $\mathrm{CH}_{2} \mathrm{Cl}_{2}$ solutions containing TBACl, TBABr or TBAI as supporting electrolyte instead of $\mathrm{TBAClO}_{4}$.

The structures of the investigated $\beta$-pyrrole substituted porphyrins are shown in Scheme 1 where the planar porphyrins are represented by $\mathrm{H}_{2} \mathrm{TPPBr}_{4}$ and $\mathrm{H}_{2} \mathrm{TPP}(\mathrm{Ph})_{4}$ and the nonplanar porphyrins by $\mathrm{H}_{2} \mathrm{TPPBr}_{8}$ and $\mathrm{H}_{2} \mathrm{TPPCl}_{8}$. The planar porphyrins were earlier shown to exhibit two well-defined oneelectron reductions in $\mathrm{CH}_{2} \mathrm{Cl}_{2}$ containing $0.1 \mathrm{M} \mathrm{TBAClO}_{4}$, while the nonplanar porphyrins exhibited complex redox behavior and coupled chemical reactions under the same solution conditions. ${ }^{[5]}$ In each case, however, when acid in the form of TFA was added to the $\mathrm{CH}_{2} \mathrm{Cl}_{2}$ solution, the porphyrin electrochemistry was then characterized by a reversible and facile two-electron reduction at low TFA concentrations and an irreversible or quasi-irreversible facile two-electron reduction at higher concentrations of TFA.

Examples of this behavior for two of the porphyrins, $\mathrm{H}_{2} \mathrm{TPP}(\mathrm{Ph})_{4}$, which is planar, and $\mathrm{H}_{2} \mathrm{TPPCl}_{8}$, which is nonplanar, are shown by the cyclic voltammograms in Figure 6 . Both compounds exhibit a reversible two-electron transfer in $\mathrm{CH}_{2} \mathrm{Cl}_{2}$ containing $0.1 \mathrm{M} \mathrm{TBAClO}_{4}$ and 1.5-2.0 equivalents TFA.

The crossover between a reversible two-electron reduction in $\mathrm{CH}_{2} \mathrm{Cl}_{2}$ containing low acid concentration to an irreversible twoelectron reduction at higher concentrations of acid (such as that illustrated in Figure 6a) is related to reaction of the doubly reduced porphyrin and formation of a protonated phlorin anion but it was not clear if changing the solvent or the supporting anion from the weakly coordinating $\mathrm{ClO}_{4}{ }^{-}$to the more strongly coordinating $\mathrm{Cl}^{-}, \mathrm{Br}^{-}$or $\mathrm{I}^{-}$would lead to a stabilization of the singly reduced $\beta$-pyrrole substituted porphyrin. It was also not clear if changes in the solvent or supporting electrolyte anion would lead to a separation of the two overlapping one-electron transfer steps into two separate one-electron transfer redox processes as also occurs for $\mathrm{H}_{2}$ TPP and described in earlier sections of this manuscript. 

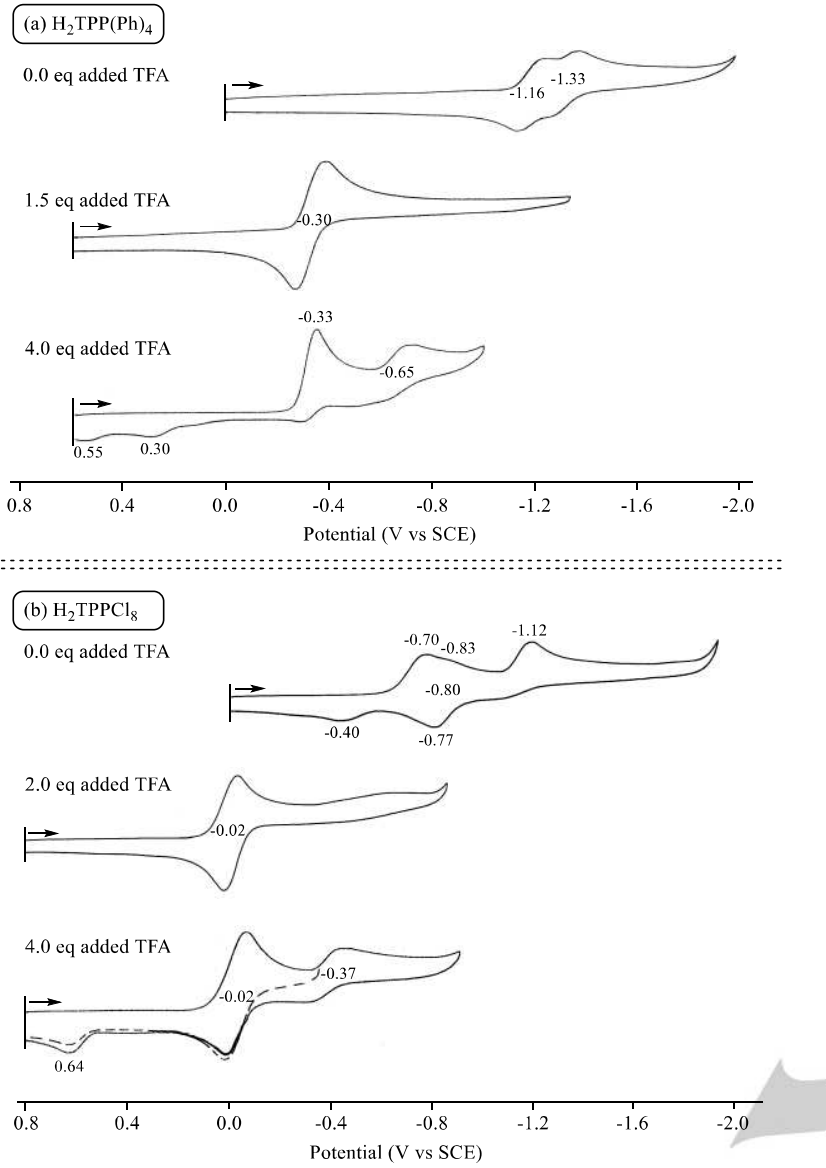

Figure 6. Comparison of cyclic voltammograms for (a) planar $\mathrm{H}_{2} \mathrm{TPP}(\mathrm{Ph})_{4}$ and (b) nonplanar $\mathrm{H}_{2} \mathrm{TPPCl}_{8}$ in $\mathrm{CH}_{2} \mathrm{Cl}_{2}$ containing $0.1 \mathrm{M} \mathrm{TBAClO}_{4}$ and different concentrations of added TFA. Scan rate $=0.1 \mathrm{~V} / \mathrm{s}$.

The answer to this question is clear cut and shown by the cyclic voltammograms in Figure 7 for $\mathrm{H}_{4} \mathrm{TPPCl}$ in $\mathrm{CH}_{2} \mathrm{Cl}_{2}$ before and after the addition of 2 eq TFA to solutions containing the four TBAX supporting electrolytes, where $\mathrm{X}=\mathrm{Cl}^{-}, \mathrm{Br}, \mathrm{I}^{-}$or $\mathrm{ClO}_{4}^{-}$. Under all four solution conditions there is a minimum amount of phlorin anion formation after the addition of acid as evidenced by the reversible redox processes and the lack of a major reduction peak following formation of the doubly reduced species. The two one-electron additions to the porphyrin m-ring system are overlapped in potential and located at $E_{1 / 2}=-0.01 \mathrm{~V}$ in the $\mathrm{CH}_{2} \mathrm{Cl}_{2}$ solutions containing $0.1 \mathrm{M} \mathrm{TBAClO}_{4}$ and 2.0 eq TFA but two well-separated one-electron transfers are seen in the $\mathrm{CH}_{2} \mathrm{Cl}_{2} / \mathrm{TFA}$ solutions containing TBACl, TBABr, or TBAl as supporting electrolyte. The first one-electron reduction of $\mathrm{H}_{4} \mathrm{TPPCl}_{8}$ is located at $E_{1 / 2}=-0.01$ to $0.02 \mathrm{~V}$ under all four solution conditions, while the half-wave potential for the second one-electron addition varies with the strength of the anion and is located at $E_{1 / 2}$ values of $-0.18,-0.13$ or $-0.12 \mathrm{~V}$ in $\mathrm{CH}_{2} \mathrm{Cl}_{2}$ solutions containing respectively, TBACl, TBABr or TBAI (Figure $7 \mathrm{~b})$. The electrode reactions under these conditions are proposed to occur as shown in Eqs 3 and 4 where all three forms of the diacid are written as being ion paired with the anion of the supporting electrolyte on the electrochemical timescale.

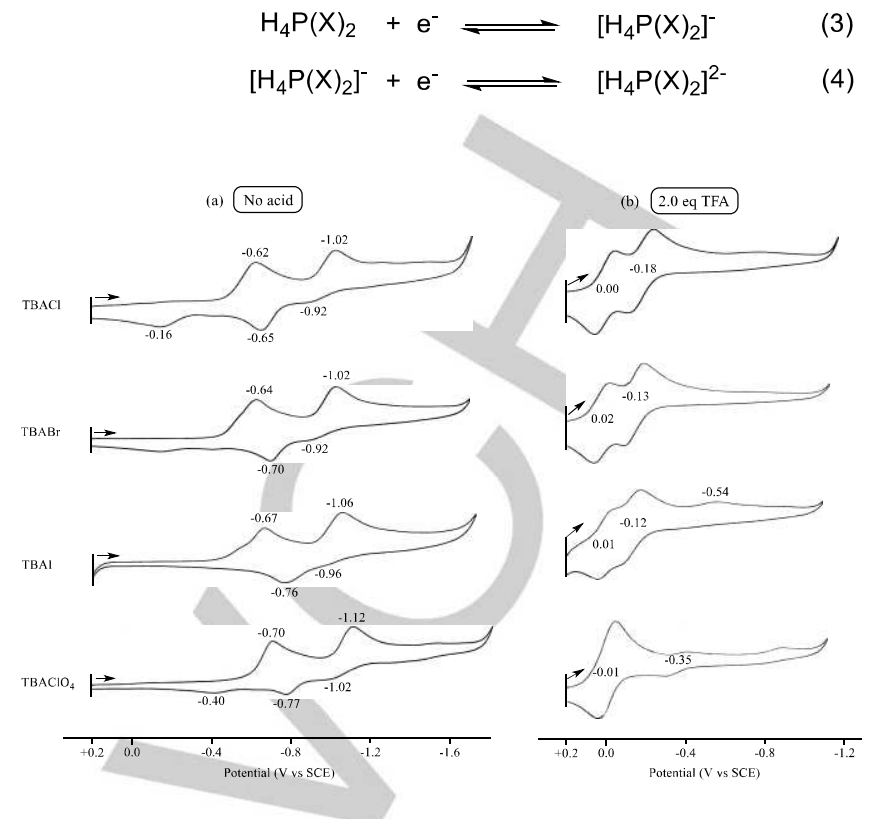

Figure 7. Cyclic voltammograms of $\mathrm{H}_{2} \mathrm{TPPCl} \mathrm{C}_{8}$ in (a) $\mathrm{CH}_{2} \mathrm{Cl}_{2}$ containing different $0.1 \mathrm{M}$ TBAX supporting electrolytes where $\mathrm{X}=\mathrm{Cl}^{-}, \mathrm{Br}, \mathrm{I}^{-}$and $\mathrm{ClO}_{4}^{-}$and (b) after adding 2.0 eq TFA to the solution. Scan rate $=0.1 \mathrm{~V} / \mathrm{s}$.

The difference in potential between the first and second oneelectron reductions of $\mathrm{H}_{4} \mathrm{TPPCl}_{8}(\mathrm{X})_{2}$ increases with increasing strength of the supporting electrolyte anion and in $\mathrm{CH}_{2} \mathrm{Cl}_{2}$ containing 2.0 eq TFA the $\Delta E_{1 / 2}$ follows the order: $\mathrm{ClO}_{4}^{-}(0 \mathrm{mV})<$ $\mathrm{I}^{-}(130 \mathrm{mV})<\mathrm{Br}^{-}(150 \mathrm{mV})<\mathrm{Cl}^{-}(180 \mathrm{mV})$. A similar trend of $\Delta E_{1 / 2}$ with change in the anion of the supporting electrolyte is also seen for the octabromoporphyrin $\mathrm{H}_{4} \mathrm{TPPBr}_{8}(\mathrm{X})_{2}$ in $\mathrm{CH}_{2} \mathrm{Cl}_{2}$ containing 2.0 eq TFA and the same four $0.1 \mathrm{M}$ TBAX supporting electrolytes. Also, like in the case of $\mathrm{H}_{4} \mathrm{TPPCl}_{8}(\mathrm{X})_{2}$ (Figure 7), the potential separation between the two oneelectron reductions at the porphyrin macrocycle is equal to zero when using $\mathrm{TBAClO}_{4}$ as supporting electrolyte and this process is then characterized by two overlapping one electron transfers at the same potential of $-0.02 \mathrm{~V}$ vs SCE.A summary of the measured values of $E_{1 / 2}$ and $\Delta E_{1 / 2}$ value is given in Table $S 2$ for the four examined $\beta$-pyrrole substituted porphyrins in acidic $\mathrm{CH}_{2} \mathrm{Cl}_{2}$ solutions containing $0.1 \mathrm{M}$ TBAX, where $X=\mathrm{Cl}^{-}, \mathrm{Br}^{-}, \mathrm{I}^{-}$ and $\mathrm{ClO}_{4}^{-}$.

\section{Thin-layer UV/Vis Spectroelectrochemistry.}

As previously described in the literature, ${ }^{[5]}$ a spectroelectrochemical monitoring of the reduction of $\left[\mathrm{H}_{4} \mathrm{TPP}\right]^{2+}$, $\left[\mathrm{H}_{4} \mathrm{TPP}(\mathrm{Ph})_{4}\right]^{2+}$ or $\left[\mathrm{H}_{4} \mathrm{TPP}(\mathrm{Br})_{4}\right]^{2+}$ in $\mathrm{CH}_{2} \mathrm{Cl}_{2}$ solutions containing 2.0 equivalents TFA led to a UV/Vis spectrum with absorption bands which were exactly the same as that for the neutral unreduced and unprotonated porphyrins in $\mathrm{CH}_{2} \mathrm{Cl}_{2}$. However, as shown in the present study, different UV/Vis spectra are obtained after reduction of the same diprotic porphyrins in $\mathrm{CH}_{2} \mathrm{Cl}_{2}$ containing $0.1 \mathrm{M}$ TBAP and higher concentrations of TFA (10 to 20 equivalents). Examples of the spectral changes obtained under these conditions are shown in Figures 8a-c for $\left[\mathrm{H}_{4} \mathrm{TPP}\right]^{2+},\left[\mathrm{H}_{4} \mathrm{TPP}(\mathrm{Ph})_{4}\right]^{2+}$ and $\left[\mathrm{H}_{4} \mathrm{TPP}(\mathrm{Br})_{4}\right]^{2+}$, respectively. 

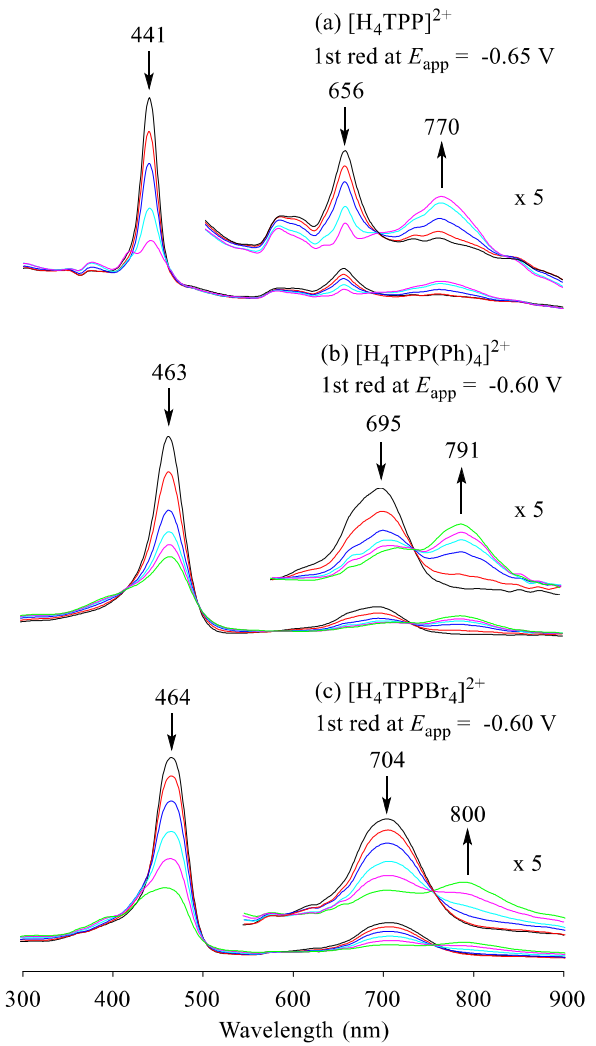

Figure 8. Thin-layer UV/Vis spectra changes of (a) $\left[\mathrm{H}_{4} \mathrm{TPP}\right]^{2+}$, (b) $\left[\mathrm{H}_{4} \mathrm{TPP}(\mathrm{Ph})_{4}\right]^{2+}$ and (c) $\left[\mathrm{H}_{4} \mathrm{TPPBr}_{4}\right]^{2+}$ during the first controlled reduction potential in $\mathrm{CH}_{2} \mathrm{Cl}_{2}$ containing 10-20 eq TFA and 0.1 $\mathrm{M} \mathrm{TBAClO}_{4}$.

The initial UV/Vis spectrum of the diprotonated compound is characterized by a Soret band at $441-464 \mathrm{~nm}$ and a broad $\mathrm{Q}$ band at 656-704 $\mathrm{nm}$. As the reduction proceeds, the Soret band absorption decreases significantly in intensity and a new intense $Q$ band appears at $770-800 \mathrm{~nm}$. Isosbestic points are observed for all three sets of spectral changes and the final spectrum of the reduced product, with bands at $770-800 \mathrm{~nm}$, is again assigned to a phlorin anion. These spectra are similar to UV/Vis spectra reported in the literature for the phlorin anions of related porphyrins. ${ }^{[6-9]}$

A different type of spectral change is seen upon reduction of the diprotonated octabromo- and octachloroporphyrins in $\mathrm{CH}_{2} \mathrm{Cl}_{2}$ solutions with excess TFA (in this case 20 equivalents). Examples of these spectral changes are shown in Figure 9. The initial UV/Vis spectrum of the unreduced porphyrins under these conditions is characterized by a Soret band at 484 or $494 \mathrm{~nm}$ and a $Q$ band at 730 or $745 \mathrm{~nm}$, all of which are red shifted as compared with bands for unreduced $\left[\mathrm{H}_{4} \mathrm{TPP}\right]^{2+},\left[\mathrm{H}_{4} \mathrm{TPP}(\mathrm{Ph})_{4}\right]^{2+}$ and $\left[\mathrm{H}_{4} \mathrm{TPPBr}_{4}\right]^{2+}$ whose spectra are shown in Figure 8.

The bleaching of the Soret band and the formation of a strong near-IR band at $770-800 \mathrm{~nm}$ upon the two electron reduction of the diprotic porphyrins in Figure 8 is consistent with generation of a phlorin anion in solution but these types of spectral changes are not seen in Figure 9 where the product of the two-electron reduction has a much decreased intensity Soret band and a broad near-IR band from $800-1000 \mathrm{~nm}$. This is strong evidence for the lack of a phlorin anion being generated upon reduction of
$\left[\mathrm{H}_{4} \mathrm{TPPCl}_{8}\right]^{2+}$ or $\left[\mathrm{H}_{4} \mathrm{TPPBr}_{8}\right]^{2+}$ on the thin-layer spectroelectrochemical timescale.

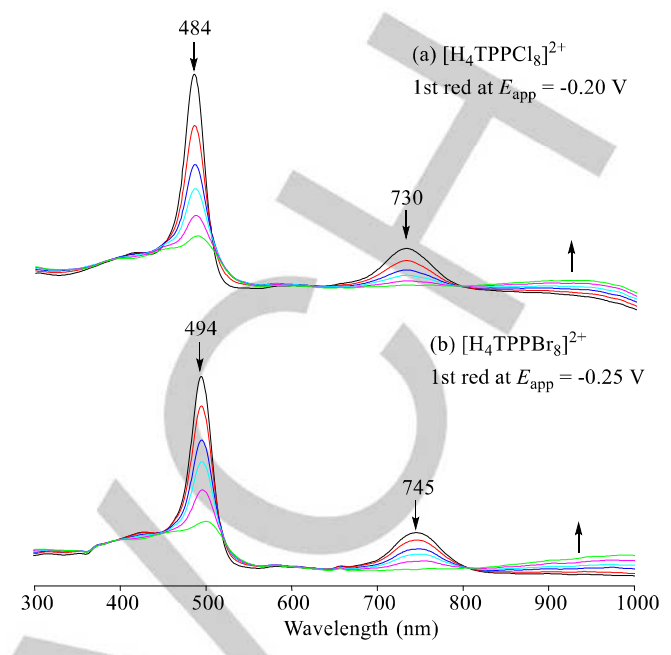

Figure 9. Thin-layer UV/Vis spectra changes of (a) $\left[\mathrm{H}_{4} \mathrm{TPPCl}_{8}\right]^{2+}$ and (b) $\left[\mathrm{H}_{4} \mathrm{TPPBr}_{8}\right]^{2+}$ during the first controlled potential reduction in $\mathrm{CH}_{2} \mathrm{Cl}_{2}$, containing $0.1 \mathrm{M} \mathrm{TBAClO}_{4}$ and 20 eq TFA

\section{Effect of Meso-Substitution on the UV/Vis Spectra of Neutral and Protonated Porphyrins}

In this section, we describe the electrochemistry, UV/Vis spectra and acid-base properties of porphyrins with zero, two, three and four meso-phenyl substituents on the macrocycle. Structures of this series of compounds are given in Scheme 2 and their UV/Vis spectra in $\mathrm{CH}_{2} \mathrm{Cl}_{2}$ are given by Table 4 . As seen from Table 4, the Soret band of each compound is systematically red shifted from 392 to $418 \mathrm{~nm}$ when increasing the number of meso-phenyl substituents from 0 to 4 and a similar red shift is seen in the four $Q$ bands which are located at 488, 519, 562 and $612 \mathrm{~nm}$ for the free-base porphine and 515, 549, 591 and 647 nm for $\mathrm{H}_{2}$ TPP in $\mathrm{CH}_{2} \mathrm{Cl}_{2}$. A plot of the Soret band wavelength vs the number of meso-phenyl groups on the porphyrin is given by Figure 10 and shows a linear relationship with a correlation coefficient of 0.997 .

The compounds in Table 4 were also spectrally monitored during conversion to their diprotic form during a titration with TFA in $\mathrm{CH}_{2} \mathrm{Cl}_{2}$. Examples of the resulting spectral changes upon conversion of the neutral porphyrin to its diprotic form are given in Figures 11 and 12 for $\mathrm{H}_{2}$ TriPP, $\mathrm{H}_{2}$ DiPP and $\mathrm{H}_{2}$ Porphine and a summary of the spectral data for the final diprotic porphyrin product is given in Table 5 which also includes the measured $\log \beta_{2}$ values in $\mathrm{CH}_{2} \mathrm{Cl}_{2}$.

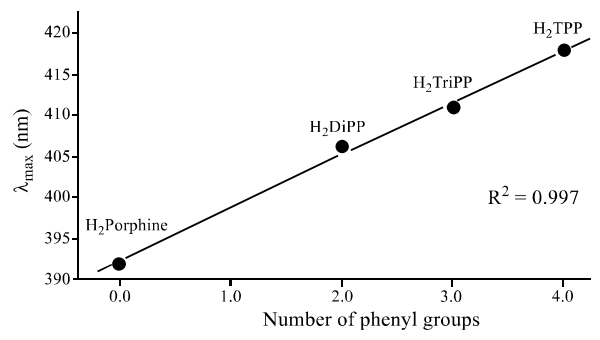

Figure 10. Plot of Soret band wavelength of the investigated porphyrins vs. number of meso-phenyl groups. 

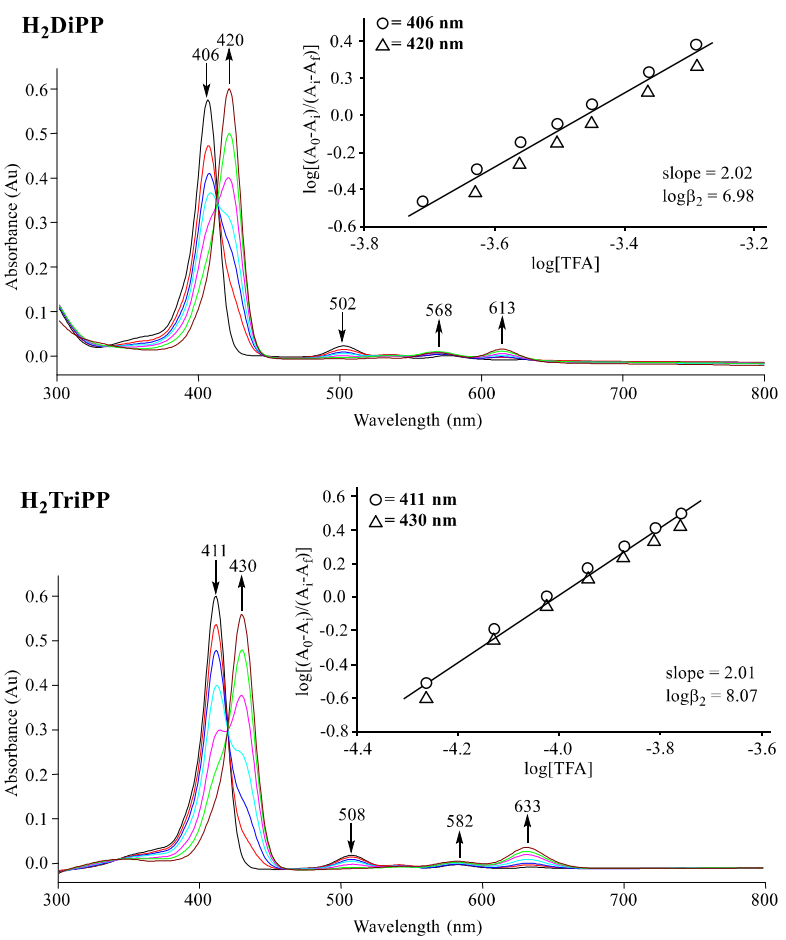

Figure 11. UV/Vis spectral changes during the protonation of $\mathrm{H}_{2} \mathrm{DiPP}$ and $\mathrm{H}_{2}$ TriPP with TFA in $\mathrm{CH}_{2} \mathrm{Cl}_{2}$. The figure inset shows the Hill plot used to analyze the data.

Like in the case of the neutral porphyrins of Scheme 2, there is a systematic red shift in the position of both the Soret band and the most intense $Q$ band in the spectrum of the diprotic porphyrins upon increasing the number of meso-phenyl groups from 0 to 4, and a plot of $\lambda_{\max } v$ s the number of phenyl groups on the compound is again linear as shown in Figure 13.

A plot of $\log \beta_{2}$ vs the number of phenyl groups on the porphyrin is also linear for the meso-substituted compounds with 2, 3 or 4 phenyl groups but $\mathrm{H}_{2}$ Porphine (the compound with zero meso-phenyl groups) does not fit this plot and proton addition to the central nitrogen atoms of the macrocycle occurs in two separate steps, with measured formation constants of $\log \mathrm{K}_{1}=$ 4.21 and $\log \mathrm{K}_{2}=1.87$.

Table 4. UV/Vis spectral data for investigated meso-phenyl substituted porphyrins in $\mathrm{CH}_{2} \mathrm{Cl}_{2}$.

\begin{tabular}{cllllll}
\hline \multirow{2}{*}{$\begin{array}{c}\text { \# of meso- } \\
\text { phenyl }\end{array}$} & Compound & \multicolumn{6}{c}{$\lambda / n m$} \\
\cline { 3 - 7 } & Soret & \multicolumn{4}{c}{ Q bands } \\
\hline 0 & $\mathrm{H}_{2}$ Porphine & 392 & 488 & 519 & 562 & 612 \\
2 & $\mathrm{H}_{2}$ DiPP & 406 & 502 & 534 & 576 & 632 \\
3 & $\mathrm{H}_{2}$ TriPP & 411 & 508 & 541 & 583 & 638 \\
4 & $\mathrm{H}_{2}$ TPP & 418 & 515 & 549 & 591 & 647 \\
0 & $\mathrm{H}_{2} \mathrm{OEP}$ & 398 & 499 & 531 & 666 & 619 \\
1 & $\mathrm{H}_{2} \mathrm{OEP}(\mathrm{Ph})$ & 404 & 503 & 537 & 572 & 625 \\
\hline
\end{tabular}

$\mathrm{H}_{2}$ Porphine mono protonation
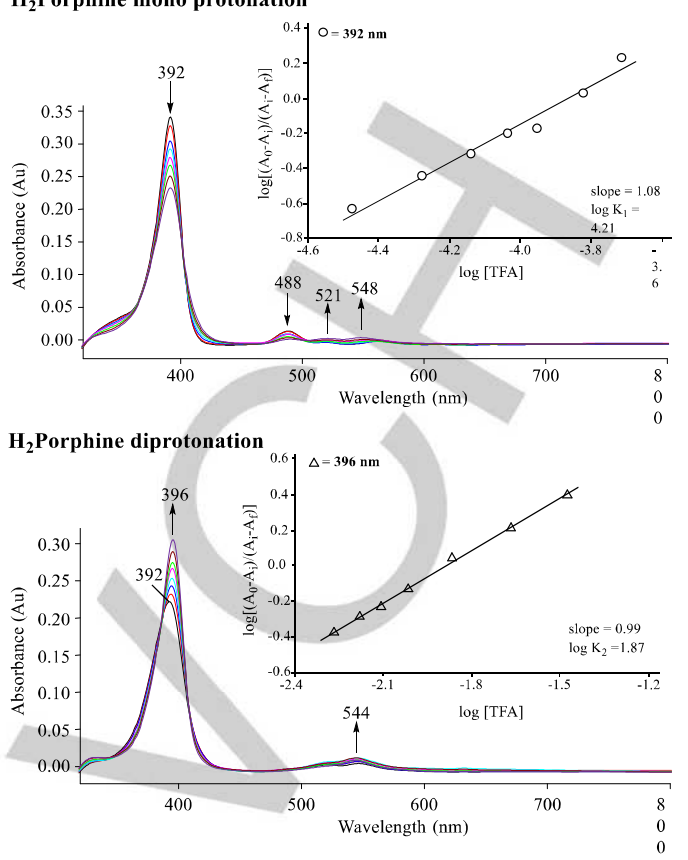

Figure 12. UV/Vis spectral changes during the first and second protonations of $\mathrm{H}_{2}$ Porphine with TFA in $\mathrm{CH}_{2} \mathrm{Cl}_{2}$. The figure inset shows the Hill plot used to analyze the data.

A similar stepwise protonation with formation of $\left[\mathrm{H}_{3} \mathrm{OEP}\right]^{+}$has earlier been reported for $\mathrm{H}_{2} \mathrm{OEP}{ }^{[50]}$ and this was confirmed in the present study which measured the binding constants in $\mathrm{CH}_{2} \mathrm{Cl}_{2}$. The relevant data are shown in Figure $\mathrm{S} 10$ where $\log \mathrm{K}_{1}=5.18$ and $\log \mathrm{K}_{2}=2.93$.

The stepwise conversion of neutral $\mathrm{H}_{2}$ Porphine and $\mathrm{H}_{2} \mathrm{OEP}$ to their monoprotic and diprotic forms (Figures 12 and S10) differs from that of the other investigated meso-phenyl substituted compounds examined in this study where a simultaneous addition of two protons to the neutral porphyrin was observed in all cases. It was therefore of interest to know what would occur for a porphyrin containing a single mesophenyl substituent and only protons at the other meso- and $\beta$ pyrrole positions of the macrocycle. Unfortunately, this porphyrin was not available for study and the closest comparison compound is given by $\mathrm{H}_{2} \mathrm{OEP}(\mathrm{Ph})$ whose structure is shown in Scheme 2.

Table 5. UV/Vis spectral data of diprotonated porphyrins and protonation constants for the investigated meso-phenyl substituted porphyrins in $\mathrm{CH}_{2} \mathrm{Cl}_{2}$.

\begin{tabular}{clcccc}
\hline $\begin{array}{c}\text { \# of meso- } \\
\text { phenyl }\end{array}$ & \multicolumn{1}{c}{ Compound } & \multicolumn{2}{c}{$\lambda / \mathrm{nm}$} & $\mathrm{n}$ & $\log \beta_{2}$ \\
\hline 0 & {$\left[\mathrm{H}_{4} \mathrm{Porphine}^{2+}\right]^{2 \mathrm{a}]}$} & 396 & 544 & 2.07 & 6.08 \\
2 & {$\left[\mathrm{H}_{4} \mathrm{DiPP}\right]^{2+}$} & 420 & 613 & 2.02 & 6.98 \\
3 & {$\left[\mathrm{H}_{4}\right.$ TriPP ${ }^{2+}$} & 430 & 633 & 2.01 & 8.07 \\
4 & {$\left[\mathrm{H}_{4} \mathrm{TPP}^{2+}\right.$} & 441 & 656 & 2.03 & 9.96 \\
0 & {$\left[\mathrm{H}_{4} \mathrm{OEP}\right]^{2+}[\mathrm{b}]$} & 403 & 547 & 2.01 & 8.11 \\
1 & {$\left[\mathrm{H}_{4} \mathrm{OEP}(\mathrm{Ph})\right]^{2+}$} & 422 & 572 & 2.02 & 10.39 \\
\hline
\end{tabular}

[a] $\mathrm{H}_{2}$ Porphine can be protonated by two steps with $\operatorname{logK}_{1}=4.21(n=1.08)$ and $\log K_{2}=1.87(n=0.99)$. Thus $\log \beta_{2}=6.08$. [b]The protonation of $\mathrm{H}_{2} \mathrm{OEP}$ occurs in two steps with $\log K_{1}=5.18 .(n=1.00)$ and $\log K_{2}=2.93(n=1.01)$. Thus $\log \beta_{2}=8.11$ 


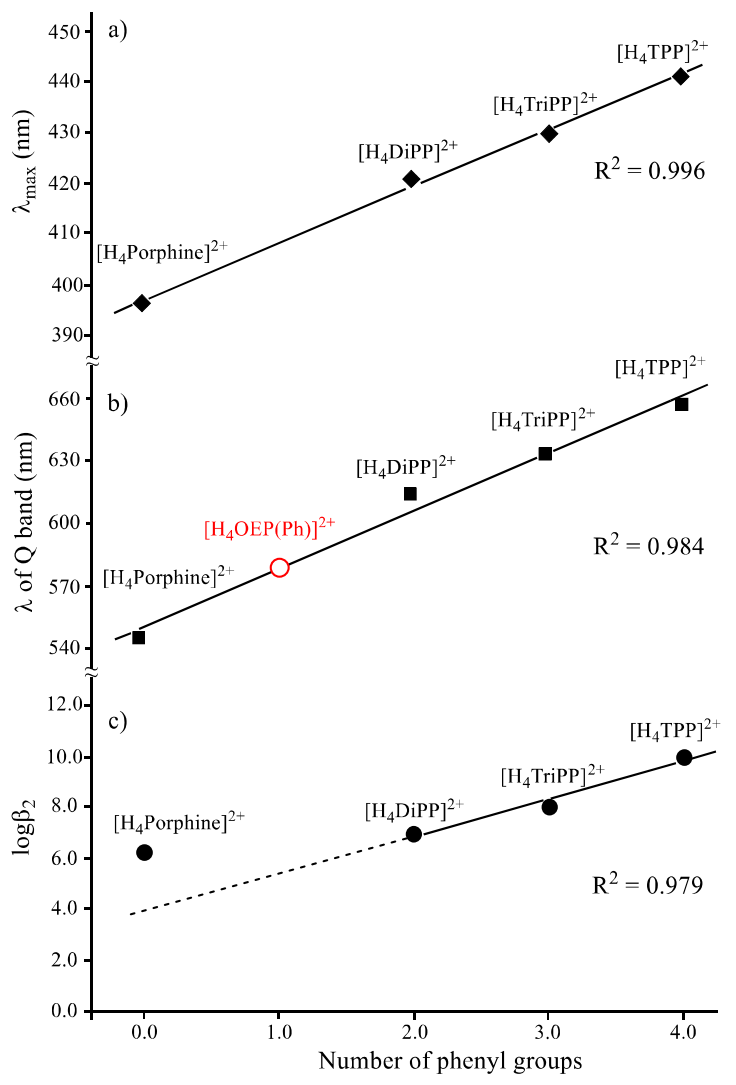

Figure 13. Correlation of a) $\lambda_{\max }(\mathrm{nm})$ of UV/Vis spectrum, b) wavelength $Q$ band $(\mathrm{nm})$ and $\mathrm{c}$ ) the diacid formation constant $\log \beta_{2}$ of meso-phenyl substituted porphyrins vs. the number of meso-phenyl substituents on macrocycle. The data were obtained in $\mathrm{CH}_{2} \mathrm{Cl}_{2}$ containing excess TFA.

Surprisingly, the conversion of $\mathrm{H}_{2} \mathrm{OEP}(\mathrm{Ph})$ to $\left[\mathrm{H}_{4} \mathrm{OEP}(\mathrm{Ph})\right]^{2+}$ was extremely facile and occurred in a single two-proton addition step with $\log \beta_{2}=10.39$. These spectral changes are shown in Figure S11 where the spectrum of the diprotonated porphyrin is characterized by an intense Soret band at $422 \mathrm{~nm}$ and a single $Q$ band at $572 \mathrm{~nm}$. These values are listed in Table 5. Neither the Soret band wavelength nor the calculated $\log \beta_{2}$ value for $\mathrm{H}_{2} \mathrm{OEP}(\mathrm{Ph})$ fit correlations between this parameter and the number of meso-phenyl groups on the macrocycle shown in Figure 13 but the wavelength of the $Q$ band does fit a correlation vs the number of meso-phenyl groups and this data point is included in Figure 13b for the correlation involving the $Q$ band position.

\section{Experimental Section}

Chemicals: Absolute dichloromethane $\left(\mathrm{CH}_{2} \mathrm{Cl}_{2}, 99.8 \%\right)$ from $\mathrm{EMD}$ Chemicals Inc. was used for electrochemistry without further purification. Benzonitrile ( $\mathrm{PhCN}$ ) was purchased from Sigma-Aldrich Chemical Co. and distilled over $\mathrm{P}_{2} \mathrm{O}_{5}$ under vacuum prior to use. N,N'dimethylformamide (DMF) and dimethyl sulfoxide (DMSO) were purchased from Sigma-Aldrich Chemical Co.. Tetra- $n$-butylammonium perchlorate $\left(\mathrm{TBAClO}_{4}\right)$, tetra- $n$-butylammonium chloride $>97 \%(\mathrm{TBACl})$, tetra- $n$-butylammonium bromide $>98 \% \quad(\mathrm{TBABr})$ and tetra- $n$ - butylammonium iodide > 99\% (TBAI), used as supporting electrolyte, were purchased from Sigma-Aldrich, recrystallized from ethyl alcohol, and dried under vacuum at $40{ }^{\circ} \mathrm{C}$ for at least one week prior to use. Trifluoroacetic Acid (TFA) > 99\% was purchased from Sigma-Aldrich Chemical Co..

5,10,15,20-tetraphenylporphyrin, 5,10,15,20-tetra(4-pyridyl)porphyrin, 5,15-diphenylporphyrin and 5,10,15-triphenylporphyrin were purchased from PorphyChem in Dijon, France. The $\beta$-pyrrole substituted free-base porphyrins in Chart $1^{46,[51-53]}$ and the free-base porphine in Chart $2^{[54,55]}$ were synthesized using literature procedures.

Instrumentation: Cyclic voltammetry was carried out with an EG\&G model 173 potentiostat/galvanostat. A homemade three-electrode electrochemistry cell was used, consisting of a platinum button or glassy carbon working electrode (diameter $=0.3 \mathrm{~mm}$ ), a platinum wire counter electrode, and a saturated calomel reference electrode (SCE). The SCE was separated from the bulk of the solution by a fritted-glass bridge of low porosity, which contained the solvent/supporting electrolyte mixture. Potentials are referenced to the SCE.

Spectroscopically monitored titrations with acid or base were carried out in a home-built $1.0 \mathrm{~cm}$ cell. Thin-layer UV-visible spectroelectrochemical experiments were also carried out with a home-build cell that has a light transparent platinum net working electrode and a cell path length of about $1.0 \mathrm{~mm} \cdot{ }^{[56]}$ Potentials were applied and monitored with an EG\&G PAR Model 173 potentiostat. Time-resolved UV-visible spectra were recorded with a Hewlett-Packard Model 8453 diode array spectrophotometer. High purity $\mathrm{N}_{2}$ from Trigas was used to deoxygenate the solution and was kept over the solution during each electrochemical and spectroscopic experiment.

Determination of Formation Constants: The changes in UV-visible spectra for each investigated free-base porphyrin in $\mathrm{CH}_{2} \mathrm{Cl}_{2}$ were monitored during a titration with trifluoroacetic acid (TFA) and the resulting spectral data then used to calculate the formation constants for proton addition by using the Hill equation ${ }^{[57,58]}$ (Eq. 5)

$$
\log \left[\left(A_{0}-A_{i}\right) /\left(A_{i}-A_{f}\right)\right]=\log K+n \log \left[H^{+}\right]
$$

where $A_{0}=$ the initial absorbance in which $\left[\mathrm{H}^{+}\right]=0.0, A_{f}=$ the final absorbance of the fully protonated porphyrin and $A_{i}=$ the absorbance at a given proton concentration during the titration. The slope of the $\log \left[\left(\mathrm{A}_{0^{-}}\right.\right.$ $\left.\left.A_{i}\right) /\left(A_{i}-A_{f}\right)\right]$ versus $\log \left[H^{+}\right]$plot gives $n$, the number of protons added to the core nitrogen atoms (or the pyridyl groups in the case of the pyridylporphyrins). The value of $\log K$ (or $\log \beta_{2}$ in most cases) was then calculated from the intercept of the line at $\log \left[\left(\mathrm{A}_{0}-\mathrm{A}_{\mathrm{i}}\right) /\left(\mathrm{A}_{\mathrm{i}}-\mathrm{A}_{\mathrm{f}}\right)\right]=0.0$. In the present study, the $\log K_{2}$ and $\log \beta_{2}$ values were evaluated by using a minimum of two wavelengths, and an average value of $n$ and log of the formation constant is reported.

\section{Acknowledgements}

Support was provided by the Robert A. Welch Foundation (KMK, Grant E-680), Natural Science Foundation of China (Grant No. 21501070), the CNRS France (UMR 6302), the "Universite de Bourgogne" and the "Conseil Régional deBourgogne" through the 3MIM-integrated project ("Marquage deMolécules par les Métaux pour I'Imagerie Médicale"). The French Ministry of Research is also acknowledged for PhD scholarship. C.H.D. 
thanks the CNRS for granting him the opportunity to work as a full-time researcher for one year ("délégation CNRS", Sept. 2015). We are thankful to Dr. Hai-Jun Xu and Dr. Yi Chang for the preparation of some porphyrin derivatives. We are very thankful to Dr. Benoit Habermeyer and Porphychem Co. for providing some porphyrin precursors.

Keywords: electrochemistry•free-base porphyrin•protonation• spectroelectrochemistry• supporting electrolyte

[1] In The Porphyrin Handbook, Vol. 1-20 (Eds.: K. M. Kadish, K. M. Smith, R. Guilard), Academic Press, New York, 2000 and 2003.

[2] In Handbook of Porphyrin Science, Vol. 1-35 (Eds.: K. M. Kadish, K. M. Smith, R. Guilard), World Scientific, Singapore, 2010-2014

[3] K. M. Kadish, in Progress in Inorganic Chemistry, Vol. 34 (Eds.: S. J. Lippard), John Wiley \& Sons, Inc. , New York, 1986, pp. 435-606.

[4] K. M. Kadish, Smith, K. M., Guilard, R., Vol. 8 (Eds.: K. M. Kadish, Van Caemelbecke, E., Royal, G. ), Academic Press, New York, 2000, pp. 1 114

[5] Y. Fang, P. Bhyrappa, Z. Ou, K. M. Kadish, Chem. - Eur. J. 2014, 20 , 524-532.

[6] G. S. Wilson, G. Peychal-Heiling, Anal. Chem. 1971, 43, 550-556.

[7] G. S. Wilson, G. Peychal-Heiling, Anal. Chem. 1971, 43, 545-550.

[8] J. G. Lanese, G. S. Wilson, J. Electrochem. Soc. 1972, 119, 1039-1043.

[9] Y. Fang, Y. G. Gorbunova, P. Chen, X. Jiang, M. Manowong, A. A. Sinelshchikova, Y. Y. Enakieva, A. G. Martynov, A. Y. Tsivadze, A. Bessmertnykh-Lemeune, C. Stern, R. Guilard, K. M. Kadish, Inorg. Chem. 2015, 54, 3501-3512.

[10] Z. Samec, J. Langmaier, A. Trojanek, S. Zalis, Vol. 34, World Scientific Publishing Co. Pte. Ltd., 2014, pp. 97-146.

[11] B. Su, F. Li, R. Partovi-Nia, C. Gros, J.-M. Barbe, Z. Samec, H. H. Girault, Chem. Commun. (Cambridge, U. K.) 2008, 5037-5038.

[12] G. De Luca, A. Romeo, L. M. Scolaro, G. Ricciardi, A. Rosa, Inorg. Chem. 2007, 46, 5979-5988.

[13] S. Thyagarajan, T. Leiding, S. P. Arskold, A. V. Cheprakov, S. A. Vinogradov, Inorg. Chem. 2010, 49, 9909-9920.

[14] O. Finikova, A. Galkin, V. Rozhkov, M. Cordero, C. Haegerhaell, S. Vinogradov, J. Am. Chem. Soc. 2003, 125, 4882-4893.

[15] A. Stone, E. B. Fleischer, J. Amer. Chem. Soc. 1968, 90, 2735-2748.

[16] D. K. Maity, R. L. Bell, T. N. Truong, J. Am. Chem. Soc. 2000, 122, 897-906.

[17] A. V. Udal'tsov, L. A. Kazarin, A. A. Sweshnikov, J. Mol. Struct. 2001 $562,227-239$.

[18] Y. Zhang, M. X. Li, M. Y. Lue, R. H. Yang, F. Liu, K. A. Li, J. Phys. Chem. A 2005, 109, 7442-7448.

[19] A. Rosa, G. Ricciardi, E. J. Baerends, A. Romeo, L. M. Scolaro, J. Phys. Chem. A 2003, 107, 11468-11482.

[20] S. Y. Ma, Chem. Phys. Lett. 2000, 332, 603-610

[21] D.-M. Chen, X. Liu, T.-J. He, F.-C. Liu, Chem. Phys. 2003, 289, 397 407.

[22] A. Rosa, G. Ricciardi, E. J. Baerends, J. Phys. Chem. A 2006, 110 5180-5190.

[23] V. N. Knyukshto, K. N. Solovyov, G. D. Egorova, Biospectroscopy 1998 , 4, 121-133.

[24] I. V. Avilov, A. Y. Panarin, V. S. Chirvony, Chem. Phys. Lett. 2004, 389, 352-358.

[25] F. Scandola, C. Chiorboli, A. Prodi, E. lengo, E. Alessio, Coord. Chem. Rev. 2006, 250, 1471-1496.
[26] V. V. Borovkov, Y. Inoue, Top. Curr. Chem. 2006, 265, 89-146.

[27] G. A. Hembury, V. V. Borovkov, Y. Inoue, Chem. Rev. (Washington, DC U. S.) 2008, 108, 1-73.

[28] L. Rosaria, A. D'Urso, A. Mammana, R. Purrello, Chirality 2008, 20 , 411-419.

[29] N. Berova, L. Di Bari, G. Pescitelli, Chem. Soc. Rev. 2007, 36, 914-931.

[30] Y. Zhang, P. Chen, Y. Ma, S. He, M. Liu, ACS Appl. Mater. Interfaces 2009, 1, 2036-2043.

[31] K. S. Chan, X. Zhou, B. S. Luo, T. C. W. Mak, J. Chem. Soc., Chem. Commun. 1994, 271-272.

[32] J.-Z. Zou, Z. Xu, M. Li, X.-Z. You, H.-Q. Wang, Acta Crystallogr., Sect. C: Cryst. Struct. Commun. 1995, C51, 760-761.

[33] M. Gruden, S. Grubisic, A. G. Coutsolelos, S. R. Niketic, J. Mol. Struct. 2001, 595, 209-224.

[34] P. Bhyrappa, M. Nethaji, V. Krishnan, Chem. Lett. 1993, 869-872.

[35] K. M. Kadish, M. M. Morrison, J. Am. Chem. Soc. 1976, 98, 3326-3328.

[36] K. M. Kadish, J. L. Cornillon, C. L. Yao, T. Malinski, G. Gritzner, J. Electroanal. Chem. Interfacial Electrochem. 1987, 235, 189-207.

[37] R. A. Ransdell, C. C. Wamser, J. Phys. Chem. 1992, 96, 10572-10575.

[38] R. C. Weast, in Handbook of Chemistry and Physics- 66th Edition, CRC Press, Boca Raton, Florida, 1985, pp. E50-52.

[39] C. Reichardt, in Solvents and Solvent Effects in Organic Chemistry, Wiley-VCH, Weinheim, 2003, pp. 23-26, 418-424.

[40] J. L. Sessler, D. Seidel, Angew. Chem., Int. Ed. 2003, 42, 5134-5175.

[41] L. Cuesta, E. Tomat, V. M. Lynch, J. L. Sessler, Chem. Commun. 2008, 3744-3746.

[42] J. M. M. Rodrigues, A. S. F. Farinha, P. V. Muteto, S. M. WoranoviczBarreira, F. A. Almeida Paz, M. G. P. M. S. Neves, J. A. S. Cavaleiro, A. C. Tome, M. T. S. R. Gomes, J. L. Sessler, J. P. C. Tome, Chem. Commun.2014, 50, 1359-1361.

[43] S. K. Kim, J. Lee, N. J. Williams, V. M. Lynch, B. P. Hay, B. A. Moyer, J. L. Sessler, J. Am. Chem. Soc. 2014, 136, 15079-15085.

[44] R. C. Jagessar, M. Shang, W. R. Scheidt, D. H. Burns, J. Am. Chem. Soc. 1998, 120, 11684-11692.

[45] Y.-H. Kim, J.-I. Hong, Tetrahedron Lett. 2000, 41, 4419-4423.

[46] P. D. Beer, M. G. B. Drew, R. Jagessar, J. Chem. Soc., Dalton Trans. 1997, 881-886.

[47] C. Bucher, C. H. Devillers, J.-C. Moutet, J. Pecaut, J. L. Sessler, Chem. Commun.2006, 3891-3893.

[48] O. Almarsson, A. Blasko, T. C. Bruice, Tetrahedron 1993, 49, 1023910252.

[49] A. J. Bard, L. R. Faulkner, John Wiley \& Sons, Inc., New York, 2001, pp. 226-260.

[50] H. H. Thanga, A. L. Verma, New J. Chem. 2002, 26, 342-346.

[51] P. K. Kumar, P. Bhyrappa, B. Varghese, Tetrahedron Lett. 2003, 44 4849-4851.

[52] T. Wijesekera, A. Matsumoto, D. Dolphin, D. Lexa, Angew. Chem. 1990 102, 1073-1074

[53] P. Bhyrappa, V. Krishnan, Inorg. Chem. 1991, 30, 239-245.

[54] C. H. Devillers, A. K. D. Dime, H. Cattey, D. Lucas, C. R. Chim. 2013 16, 540-549.

[55] D. K. Dogutan, M. Ptaszek, J. S. Lindsey, J. Org. Chem. 2007, 72, 5008-5011.

[56] X. Q. Lin, K. M. Kadish, Anal. Chem. 1985, 57, 1498-1501.

[57] P. E. Ellis, Jr., J. E. Linard, T. Szymanski, R. D. Jones, J. R. Budge, F. Basolo, J. Am. Chem. Soc. 1980, 102, 1889-1896.

[58] D. Brault, M. Rougee, Biochemistry 1974, 13, 4591-4597. 


\section{FULL PAPER}

The combined effects of solution conditions and macrocyclic structure determine the redox behavior of freebase porphyrins in acidic nonaqueous media. Each porphyrin undergoes two reductions at the $\pi$-ring system which occur in well-separated or overlapping electron transfer steps at potentials between 0.00 and $-1.36 \mathrm{~V}$ vs SCE. Protonation constants were obtained and spectra of the electroreduced diprotic porphyrins were characterized byspectroelectrochemistry.

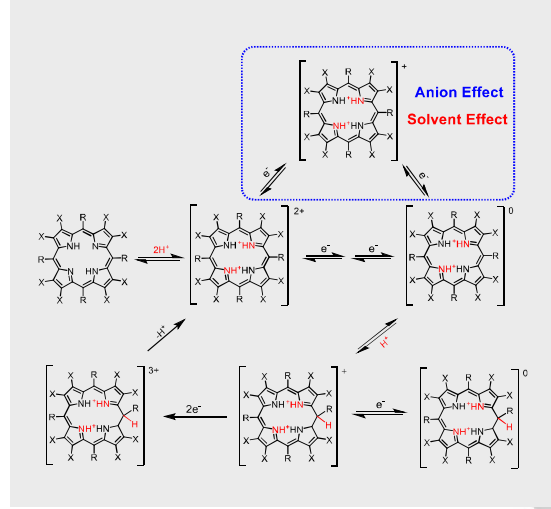

Y. Cui, ${ }^{[a]}$ L. Zeng, ${ }^{[a]}$ Y. Fang, ${ }^{[a]} \mathrm{J}$. Zhu, ${ }^{[a]}$ C. H. Devillers, ${ }^{[b]}$ D. Lucas, ${ }^{[b]} N$. Desbois, ${ }^{[b]}$ C. P. Gros, ${ }^{*[b]}$ Karl M. Kadish ${ }^{\star[a]}$

Page No. - Page No.

Tuning the Electrochemistry of FreeBase Porphyrins in Acidic Nonaqueous Media:Influence of Solvent, Supporting Electrolyte and RingSubstituents 